\title{
LA EXPRESIÓN PICTÓRICA RELIGIOSA Y LA SOCIEDAD COLONIAL*
}

\section{Elisa Vargas Lugo}

\author{
Al magnílico médico Vicente Guarner, este \\ minimo atisbo dentro de la historia de nuestra \\ identidad
}

Es un hecho indiscutible y determinante, el carácter eminentemente religioso de la pintura colonial hispanoamericana. Debido a esta calidad prepotente y consabida y por considerar que - por principio - la actividad pictórica del Nuevo Mundo no podía ser más que una consecuencia meramente "colonial" del desarrollo artístico de la Metrópoli, su estudio pocas veces se ha enfocado con la intención de penetrar dentro del peculiar fenómeno estético que la informa. Salvo excepción, ' los estudios más extensos y numerosos que hasta ahora se han hecho sobre pintura colonial de caballete se han basado fundamentalmente en el aspecto estilístico, lo cual no ha sido suficiente para destacar las intenciones expresivas de la sociedad que produjo tan abundantísimo acervo. En general el valor piadoso de la pintura colonial se ha aceptado sin tratar de calificarlo dentro de su contexto americano, sino como simple trasplante automático de la voluntad artística católica española. Si bien esto es cierto en gran medida, también es cierto que aqui la pintura adquirió carácter diferenciado - aunque sea en medida menor dadas las rigidas normas que limitaban la expresión artistica - pero que vale la pena enfocar - hasta donde sea posible - desde su intimidad histórica y no sólo desde las miras europeas.

La finalidad, pues de este trabajo, es tratar de explicar - al margen de consideraciones estilisticas - por qué nuestra pintura colonial barroca es como es y no de otra manera y señalar, a mi entender, sus significados expresivos, considerada como producto de la sociedad americana, compleja y heterogénea.

Me excuso de antemano por recurrir constantemente y con decidida preferencia al campo histórico-artístico de la Nueva España, que por razones obvias me sirve de fundamento.

Para facilitar la comprensión del fenómeno estético en la pintura colonial barroca es necesario revisar en algunos de sus puntos el desarrollo de este arte durante el siglo XVI americano.

El culto a las imágenes se considera tradición recibida de San Pedro y la

* Parte de un estudio más amplio sobre el lénómeno estético en el batroco mexicano.

1 Por ejemplo el importante trabajo de I rancisco Stasny que estudia a través de la iconogratia el sincretismo cultural que infor ma las representaciones de los ángeles arcabuceros de la pintura andinat 
primera vez que se trató como problema fue en el concilio de Nicea, del año 787. ${ }^{2}$ El documento dice:

"Habiendo empleado todo el posible cuidado y exactitud, decidimos que las Santas Imágenes que sean pintadas ${ }^{3}$... deben estar expuestas como (lo está) la figura de la Cruz de Nuestro Señor Jesucristo, así en las iglesias, vasos y ornamentos sagrados, paredes y tablas, como en las casas y los caminos..."

Se asentó además que la veneración no se daba a las figuras mismas sino a lo que representaban y se justificó su necesidad en la liturgia ${ }^{4}$ Asi quedaron oficialmente asentados los principios fundamentales sobre los cuales la Iglesia apoyaría siempre el culto a las imágenes

Después de siglos de calma, a raiz de la reforma luterana, en la Sesión XXV del Concilio de Trento, celebrado en 1563, se dio el decreto de la invocación, veneración y reliquias de los santos y de las sagradas imágenes; texto breve $\mathrm{y}$ ejemplar que resume el criterio artístico eclesiástico. En este documento sobresalen cuatro puntos importantísimos en relación con la expresión pictórica, que habían de continuar vigentes en la producción barroca americana: a) la honestidad de las representaciones y sus adornos, para eliminar figuras provocativas o deshonestas y apócrifas; b) censura absoluta pará las imágenes desusadas y las implicaciones supersticiosas; c) énfasis en la función didáctica de la pintura, dedicada a la instrucción " ". de la ignorante plebe", y d) afirmación del valor simbólico, al insistir que el honor que se rinde a las imágenes "....se refiere a los originales representados en ellas ...cuya semejanza tienen"."

Desde antes de 1563, en la Nueva España la Iglesia había tomado medidas para controlar la expresión artística, cosa que debe haber sucedido en toda América hispana. Así, en el Primer Concilio Mexicano en 1555, ya se había dicho que: "... ni los indios ni los españoles hicieran imágenes sin que antes hubieran sido examinados..." y se exigía que las imágenes fueran honestas y decentemente ataviadas. ${ }^{6}$ Diez años después se convocó al II Concilio Mexicano para recibir, conocer y aplicar los decretos del ecuménico Concilio de Trento; sobre pintura se aplicó lo que quedó anotado arriba.

Manuel Toussaint en su libro Pintura Colonial en México, informa que las Constituciones Sinodales resultantes del Concilio de 1555 entregaban

" Según consta en la Sesión II del Concilio de Nicea, del año 787, un fuerte brote iconoclasta, encabezado por el emperador León Isauro de Constantinopla, dio origen a este Concilio Cfr. Juan de Tejada y Ramiro. Coleccún de Cánones y de todos los Concilios de la Iglesia de España y de Amérna Madrid 1849-59, T. 111 p. 810.

${ }^{3}$ Se refiere sólo a obras pintadas pues tal vez las representaciones escultóricas eran entonces, escasas, dentro de los templos.

4uan Tejeda y Ramiro, Op. al p 812

; Hidem T IV Concluo de Trento, 1563 Se recomendó además que todo lo nuevo e inusitado que surgiera debía consultarse con el Romano Pontífice.

6 Ibulem T V p 143 
"... prácticamente la pintura en manos de las autoridades eclesiásticas, pues la Iglesia pretendía hasta poner el valor y precio de las obras" " Al parecer ante esta presión el grupo de pintores que para entonces existía en México, promovió la redacción de las primeras Ordenanzas de 1557, buscando defenderse de la inevitable libre competencia, ya que indios y espanoles sin estudios " ...tienen por granjería nombrarse (pintores o escultores) y no lo son".

Las Ordenanzas, -incluyendo las posteriores de 1686- conjunto de reglas, preceptos y mandatos de tipo técnico, como producto de su tiempo, no consideraron ninguna categoría intelectual o subjetiva en la elaboración de las pinturas. Son, sin remedio, - como ya he dicho en otro lugar- producto rígido y fiel de las recomendaciones de los Concitios, con base, naturalmente, en el concepto escolástico artesanal del arte.. Desde el punto de vista técnico las Ordenanzas, exigían de los aspirantes a pintor verdadera habilidad en el oficio, pero los conocimientos teóricos se reducían a la historia sagrada y a los dogmas de la $\mathrm{Fe}^{9}{ }^{9}$ Por lo tanto si las Ordenanzas pudieron haber servido para defender los derechos de los pintores examinados, no ofrecieron ningún recurso para estimular la expresión.

El Tercer Concilio Mexicano celebrado en 1585, insistió en el carácter utilitario de las imágenes como medios de expresión y para evitar errores recomendó el uso de los tratados de Juan Interián de Ayala, de Molano y el diccionario del abate Migne ${ }^{10}$ Cabe aquí recordar la existencia de Veedores de Imaginería o sea inspectores, desde por lo menos $1555^{11}$

En la segunda mitad del XVI o sea precisamente cuando la primera generación de pintores americanos alcanzaba la plenitud de su edad y la madurez de oficio, la expresión artística se veía cautiva por las Ordenanzas y los Concilios. El trasplante de la pintura religiosa se hizo a América por medio de pintores europeos que, como consta por las obras que nos dejaron, iniciaron la producción y la enseñanza de la pintura con estricto apego a las directrices arriba anotadas.

Por otra parte es un hecho que, aunque los cánones tridentinos no se propusieron para crear un estilo, inevitablemente provocaron la búsqueda de un ideal de belleza sagrada ${ }^{12}$ que a mi juicio, en la pintura colonial americana, encontró su más fiel paradigma en la época barroca. Basta comparar obras de Simón Pereyns (figura 1), con las de Bitti (figura 2), o Angelino Medoro (figura 3) -iniciadores del arte de la pintura en Améri-

\footnotetext{
7 Manuel Toussaint Pintura Colonal en México. México, UNAM 1965 p 34.

${ }^{8}$ Ernesto Chinchilla y Aguilar. Ordenanzas de Carptnteros, Escultores, Entalladores, Ensambladores y liolerus de la ciudad de México. Guatemala Antropología e Historia de Guatemala. s/t p 30.

${ }^{9}$ Ibidem p 39

10 Conclio Terero Prouncial Mexicano Celebrado en México en 1585 Publicado por Mariano Galván Rivera Notas del R.P. Basilio Arrillaga México Eugenio Maillefort y Cía 1859 p. 536.

11 Manuel Toussaint. $O p$ it. p. 37

${ }^{12}$ Cfr Elisa Vargas Lugo La lglesia de Santa Prisca de Taxco. México. UNAM 1972.
} 
ca - para aceptar que desde buen principio el mensaje piadoso de expresión honesta, recatada, dulce y de fácil comprensión, fue una obligada consigna en el arte pictórico ya que de la obra de estos artistas dependería el carácter futuro de la pintura colonial.

Muy significativo de lo consciente y premeditado de esta manera de pintar, parece ser el hecho - registrado por Francisco Stasny-13 de que Mateo Pérez de Alessio y Angelino Medoro hubieron de modificar sus aspiraciones propiamente manieristas, en cuanto comenzaron a pintar en América. Estoy también de acuerdo con este especialista en afirmar que la pintura propiamente manierista "...a base de expresiones extremadamente re. buscadas y cultas, compuestas en 'contrapunto' a las grandes obras del alto Renacimiento- simplemente no tenían cabida en el horizonte americano" 14

Un hecho semejante al cambio de expresión en Pérez de Alessio y Medoro - de sumo interés para el futuro desarrollo de la pintura barroca mexicana- ocurrió con la obra de Baltasar de Echave Orio ${ }^{15}$ Este pintó hacia 1595, las tablas para el retablo del templo de la Profesa y en 1609 las del retablo del templo de Tlatelolco, con todas las características formales requeridas por los cánones tridentinos. Sin embargo en 1605 y después en 1612 firmó dos grandes lienzos sobre los martirios de San Ponciano y San Aproniano (ligura 4), respectivamente. Estas obras por sus escorzos y composición efectista pueden considerarse la máxima creación del manierismo en la Nueva España. Sin embargo resultan atípicas dentro del desarrollo pictórico colonial y no tuvieron mayor trascendencia, ni en la obra del mismo pintor ni en la de su hijo u otros discípulos. La explicación más lógica que cabe para la rápida desaparición de este interesante y aislado brote de manierismo, es que la Iglesia lo combatió por desusado y por no ajustarse a la necesidad fundamental de ser una expresión fácilmente inteligible; pues no puede ser casual que por encima de todo hubiera prevalecido, de manera tan preponderante, el dulce y moderado tono de recatado clasicismo de Simón Pereyns, Andrés de la Concha (figura 5), y otros.

Al evitarse obras como los martirios de Echave se frenó definitivamente el estímulo para una aportación subjetiva en la pintura colonial; y la posibilidad de buscar otras directrices, se cerró aún más ya que los artistas continuaron cautivos por los caminos de la contra-maniera y la antimaniera - conceptos emitidos en el valioso estudio del profesor Stasny - en la decidida lucha de la Iglesia por encontrar "la expresión religiosa directa

13 Francisco Stasny "Vaniera y Comlra-mantera en la finlura latinoamericana". Ponencia presentada en el Coloquio Internacional La Diáspora del Manierismo Instituto de Investigaciones Estéticas de la UNA.M. Oaxtepec. 1976. Inédito

1. Hidem.

"Cfr. "Una aproximación al fenómeno estético en la pintura y escultura del barroco mexicano". Ponencia para el Simposio de Arte Hispanoamericano que tuvo lugar en la Universidad de la Rábida, España, en 1977 En prensa. 
DOI: http://dx.doi.org/10.22201/iie.18703062e.1982.50\%20Tomo\%201.1141

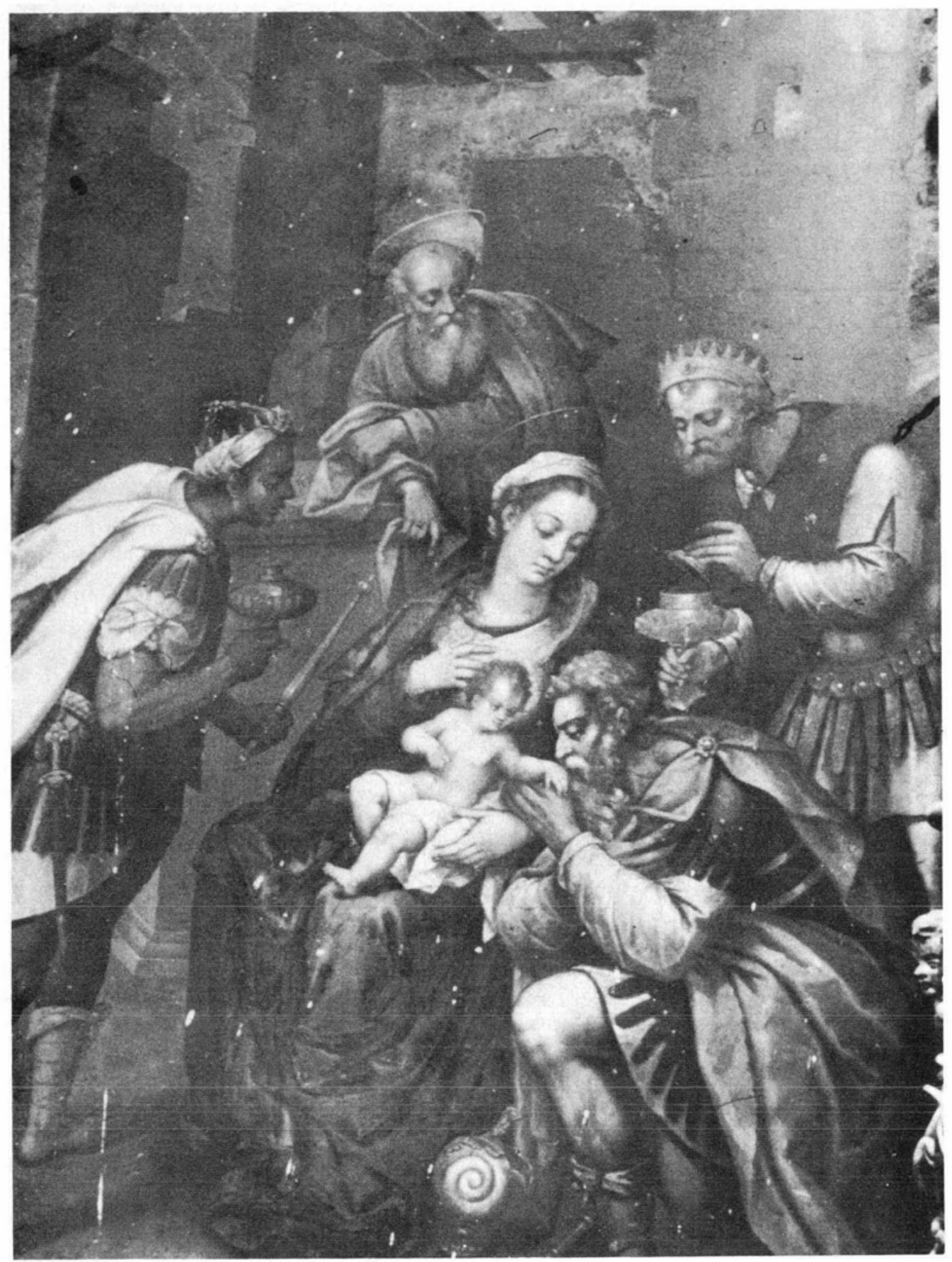

Figura 1. Simón Pereyns Adoración de los Reyes S. XVI. Retablo mayor del templo franciscano de Huejotzingo, Pue. 
DOI: http://dx.doi.org/10.22201/iie.18703062e.1982.50\%20Tomo\%201.1141

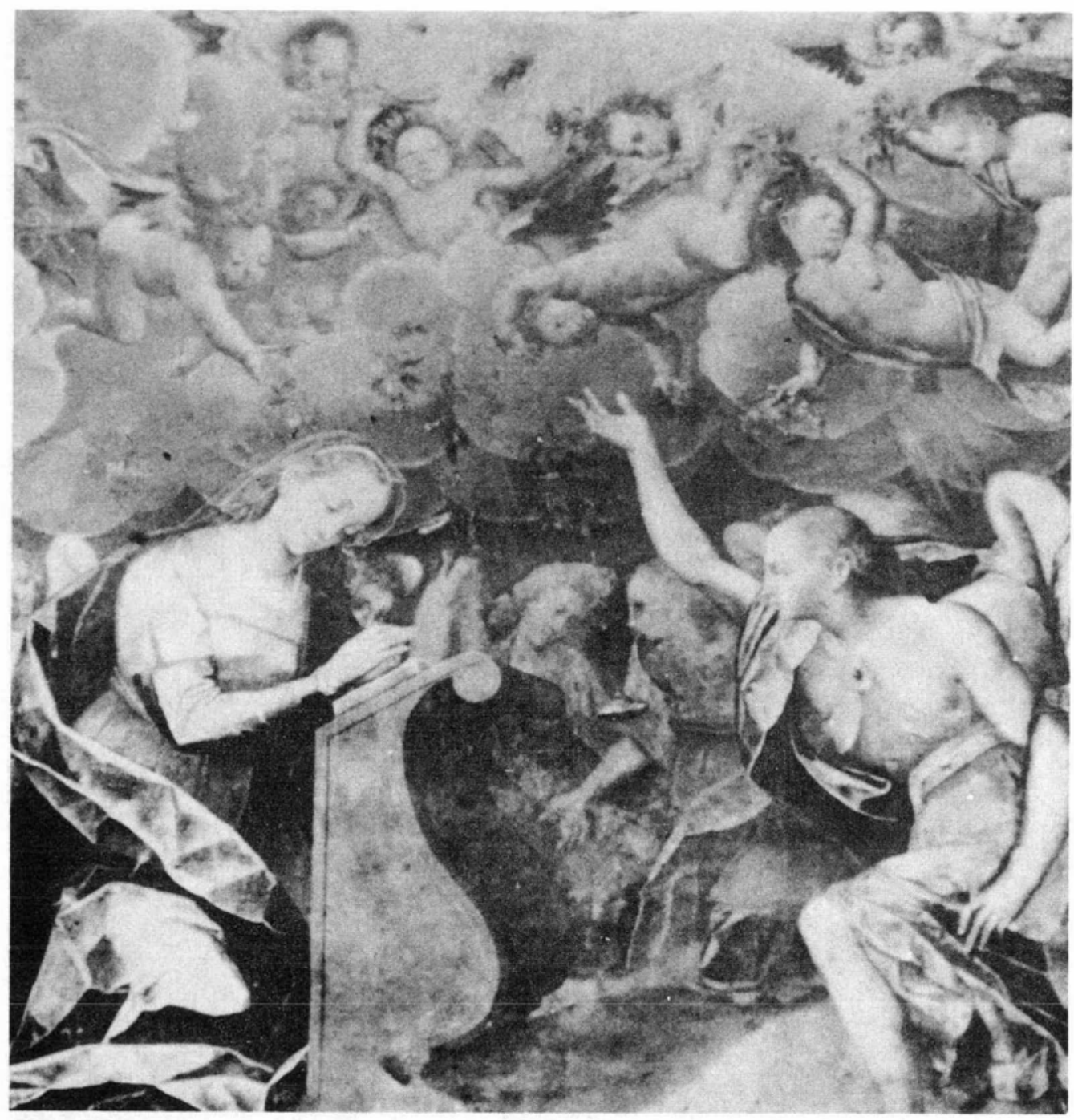

Figura 2. Bernardo Bitti. Anunciación. S. XVI. Retablo de la Iglesia de la Compañía de Jesús en Chuquisaca. Actualmente en el Museo de la catedral de Sucre. Bolivia. 


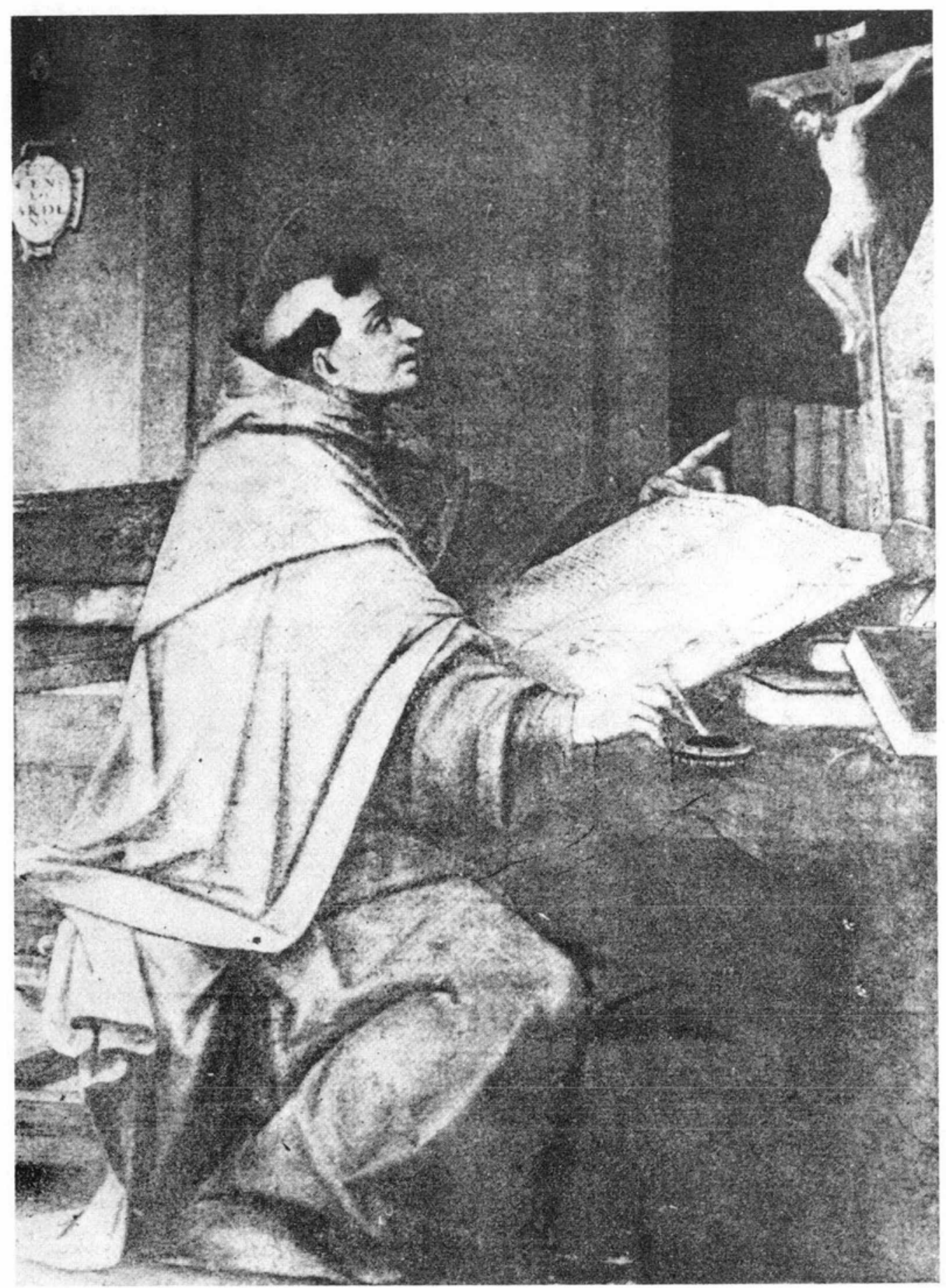

Figura 3. Angelino Medoro. San Buenaventura, 1603. Convento de San Francisco Lima, Perú. 
DOI: http://dx.doi.org/10.22201/iie.18703062e.1982.50\%20Tomo\%201.1141

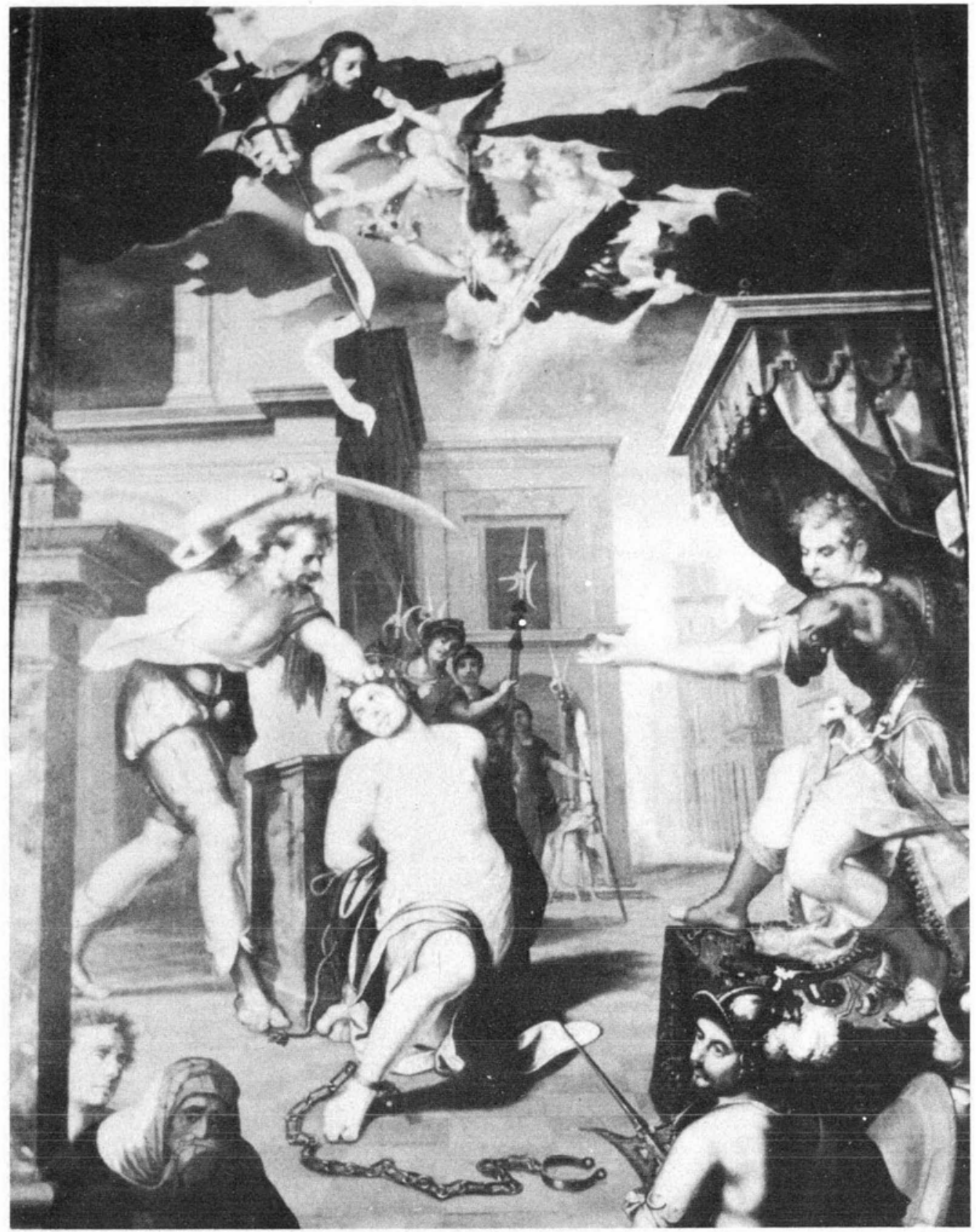

Figura 4. Baltazar de Echave Orio. Martirio de San Apromiano, 1612. Pinacoteca Virreinal. México, D. F. 
DOI: http://dx.doi.org/10.22201/iie.18703062e.1982.50\%20Tomo\%201.1141

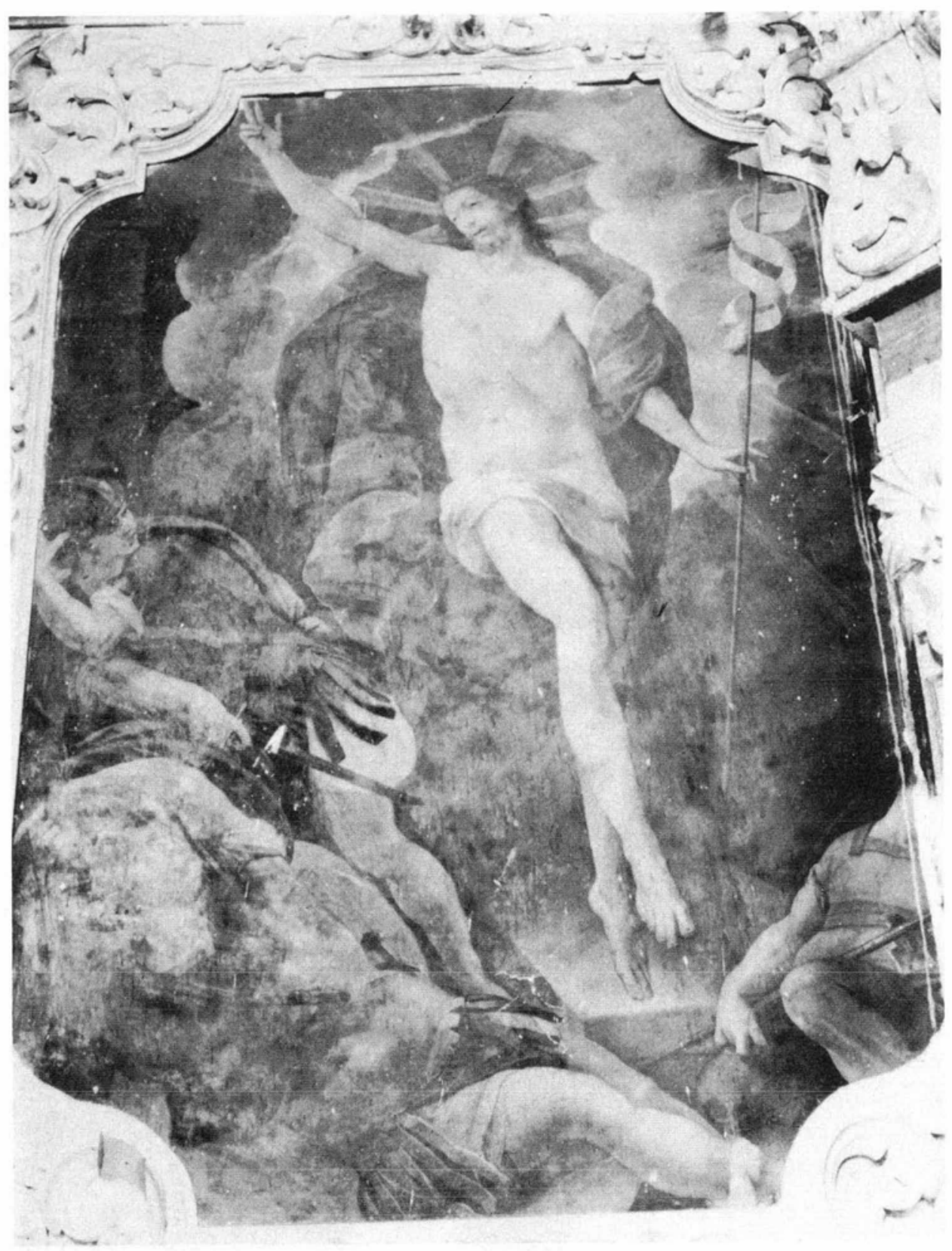

Figura 5. Andrés de la Concha. Ascención. Coixtlahuaca, Oax. 


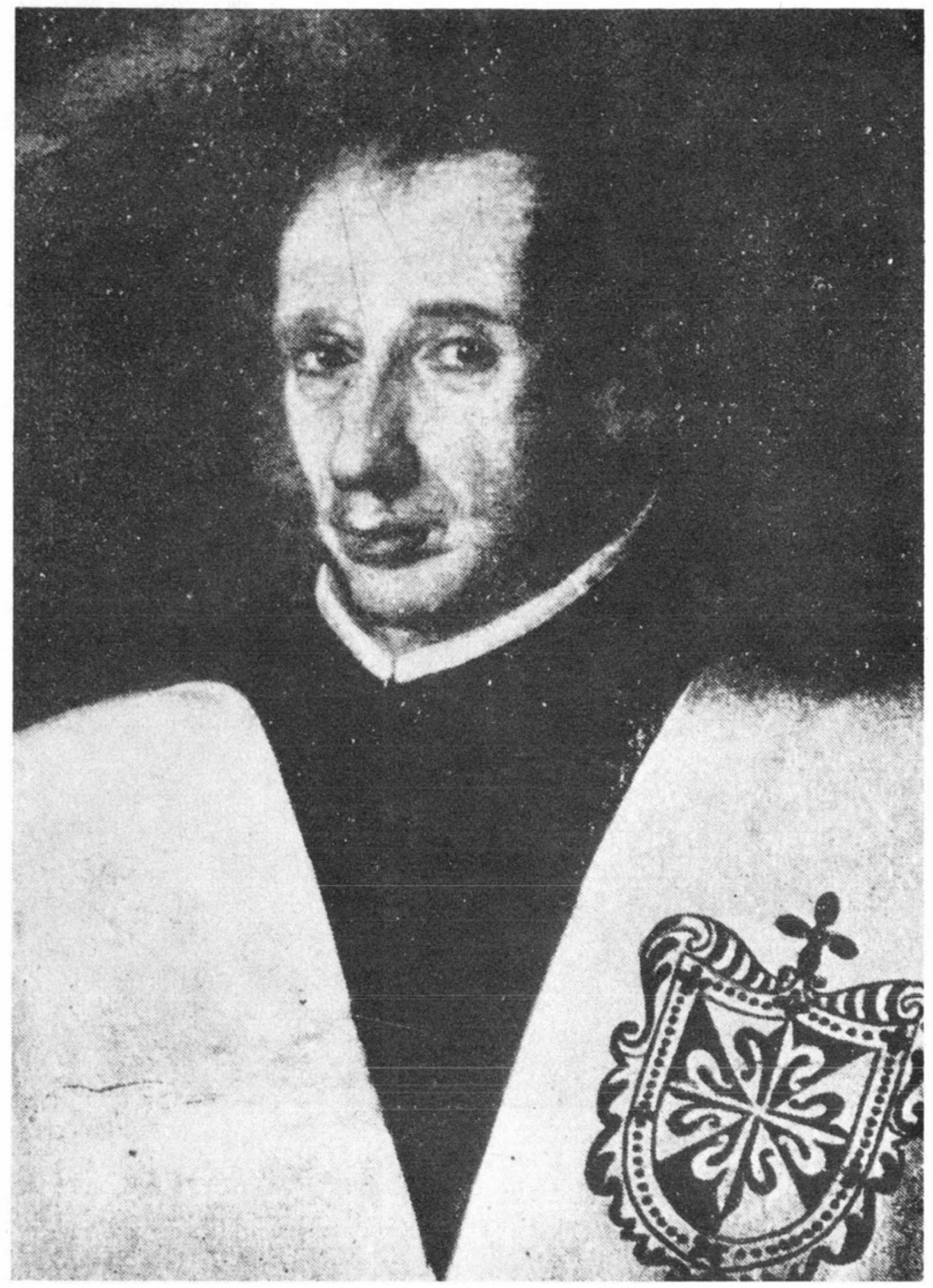

Figura 6. Gregorio Vázquez. Enrique Caldas Barbosa, 1698. Colegio del Rosario. Bogotá, Colombia. 
DOI: http://dx.doi.org/10.22201/iie.18703062e.1982.50\%20Tomo\%201.1141

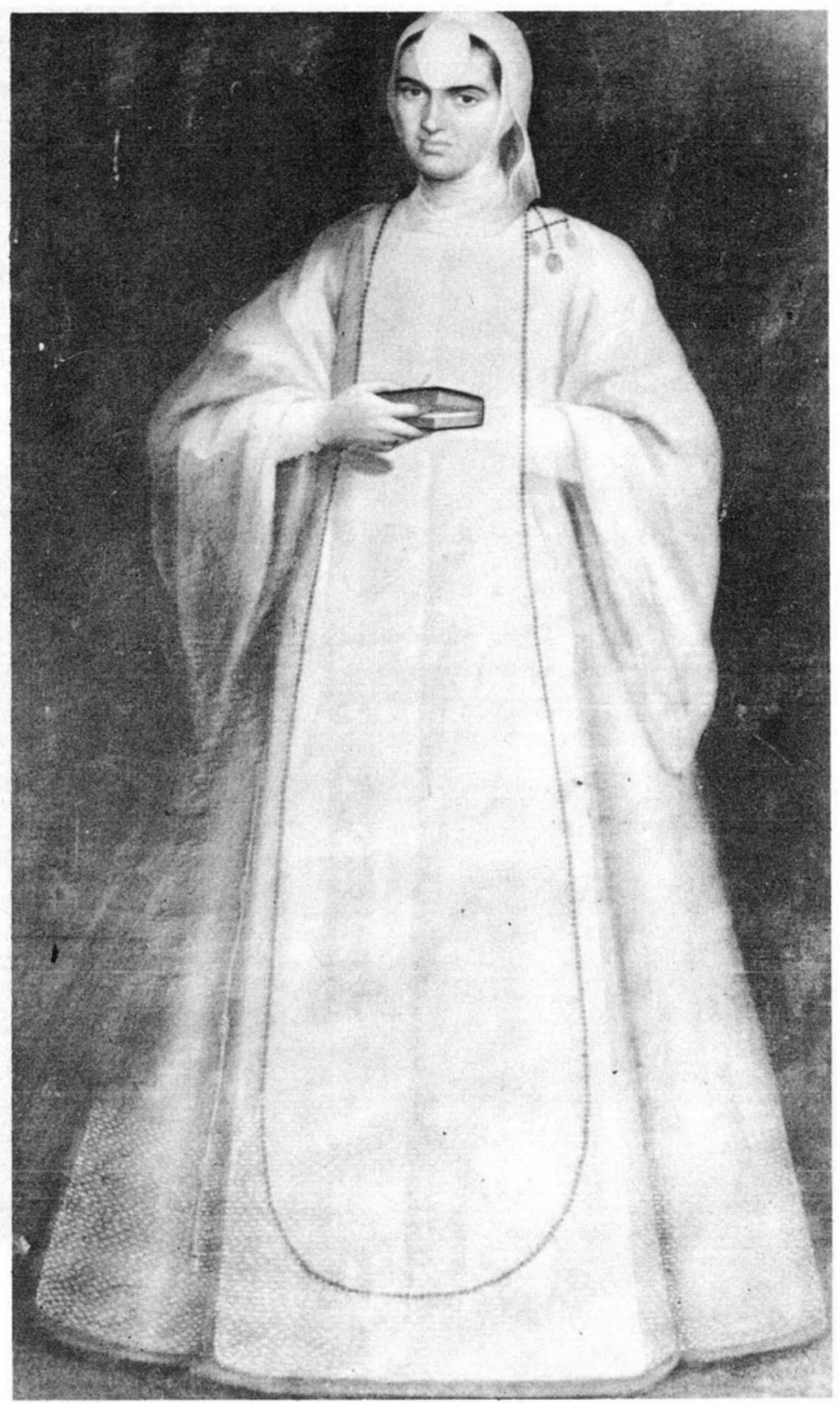

Figura 7. Anónimo. Sor Ana de Neve. Sacristía del Colegio de Santa Rosa de Viterbo, Querétaro, Qro. 


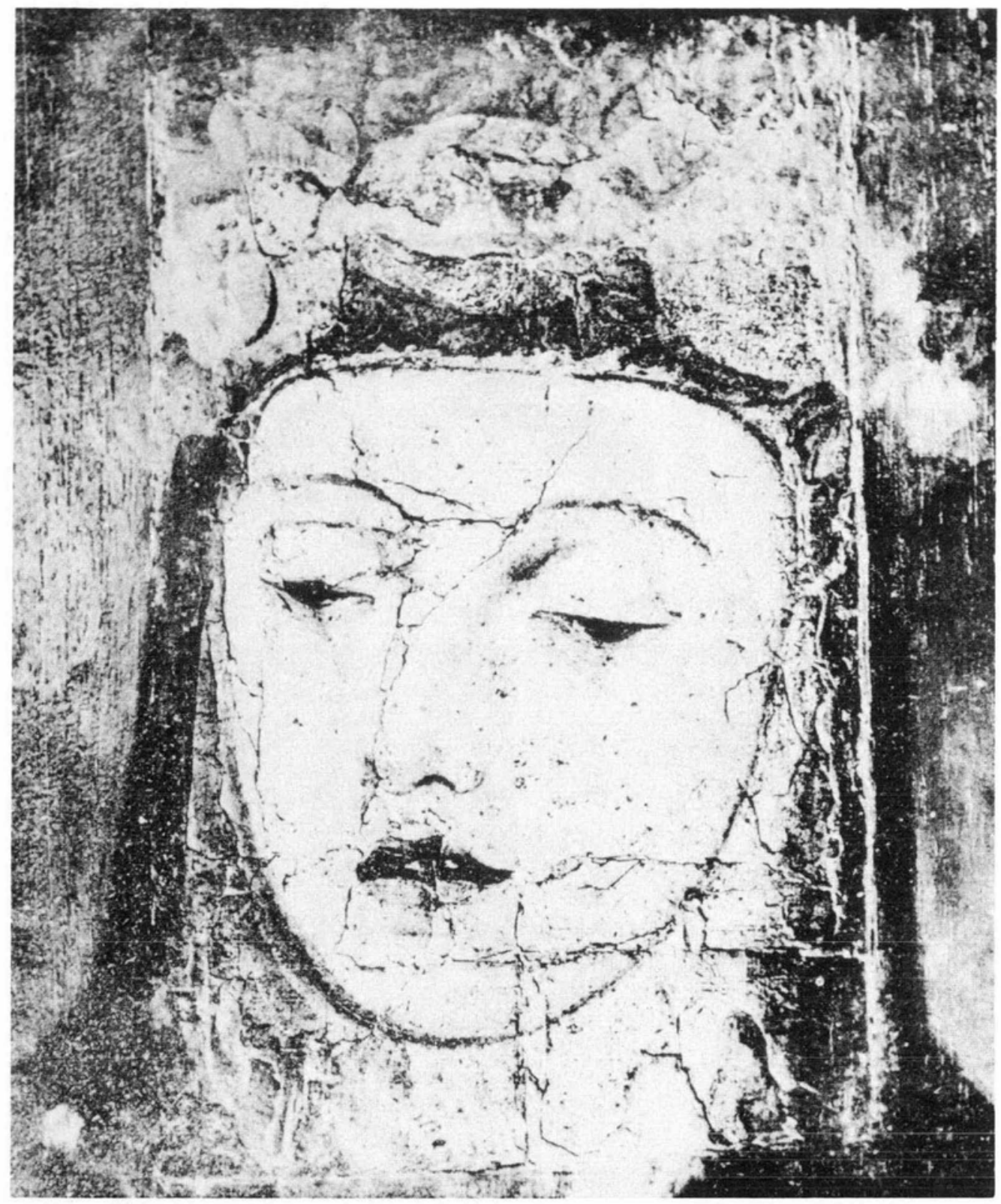

Figura 8. Angelino Medoro. Santa Rosa de Lima. 1617. Lima, Perú. 
DOI: http://dx.doi.org/10.22201/iie.18703062e.1982.50\%20Tomo\%201.1141

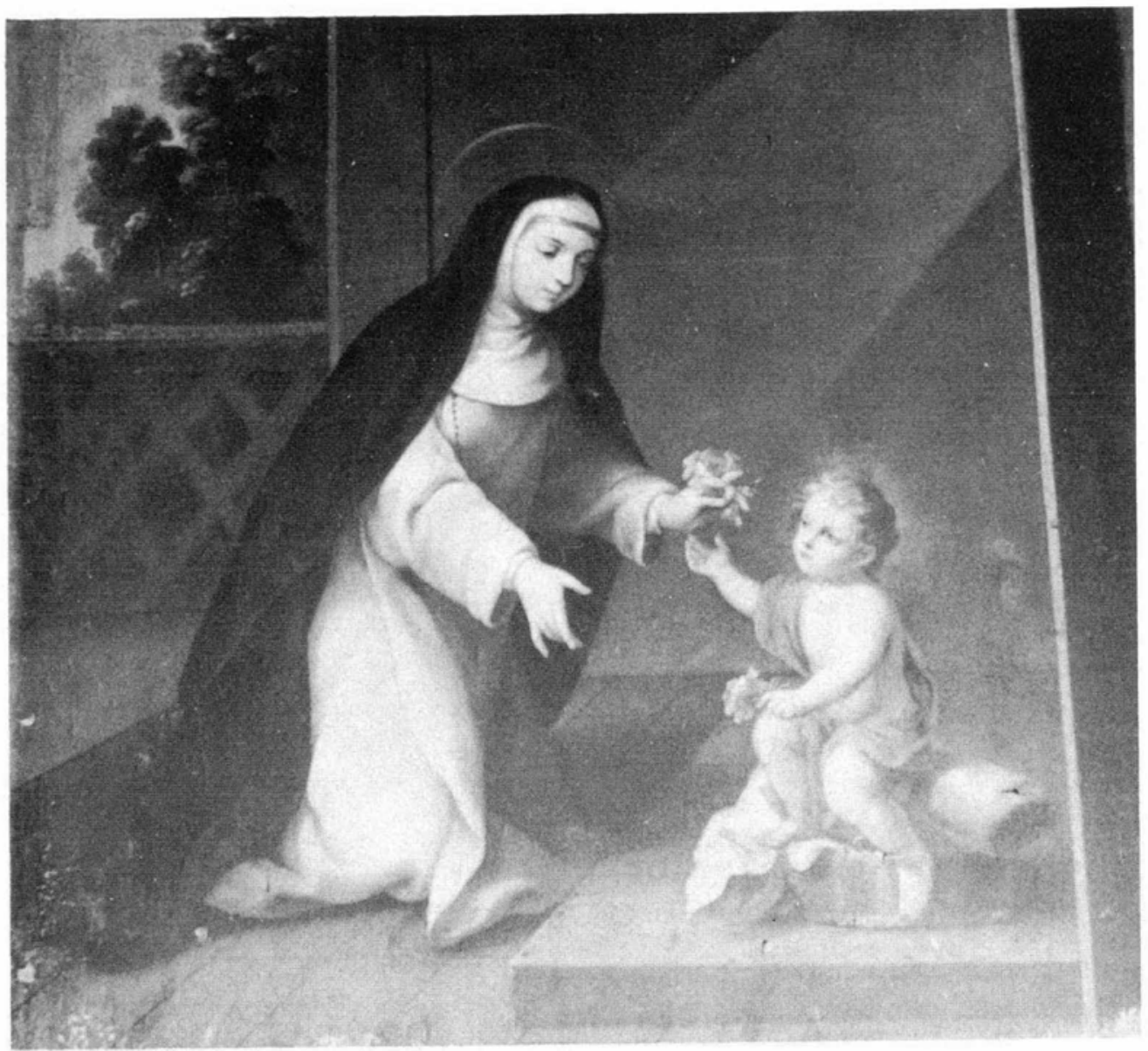

Figura 9. Anónimo. Santa Rosa de Lima. S. XVIII. Colegio de los Vizcainos. México, D. F. 


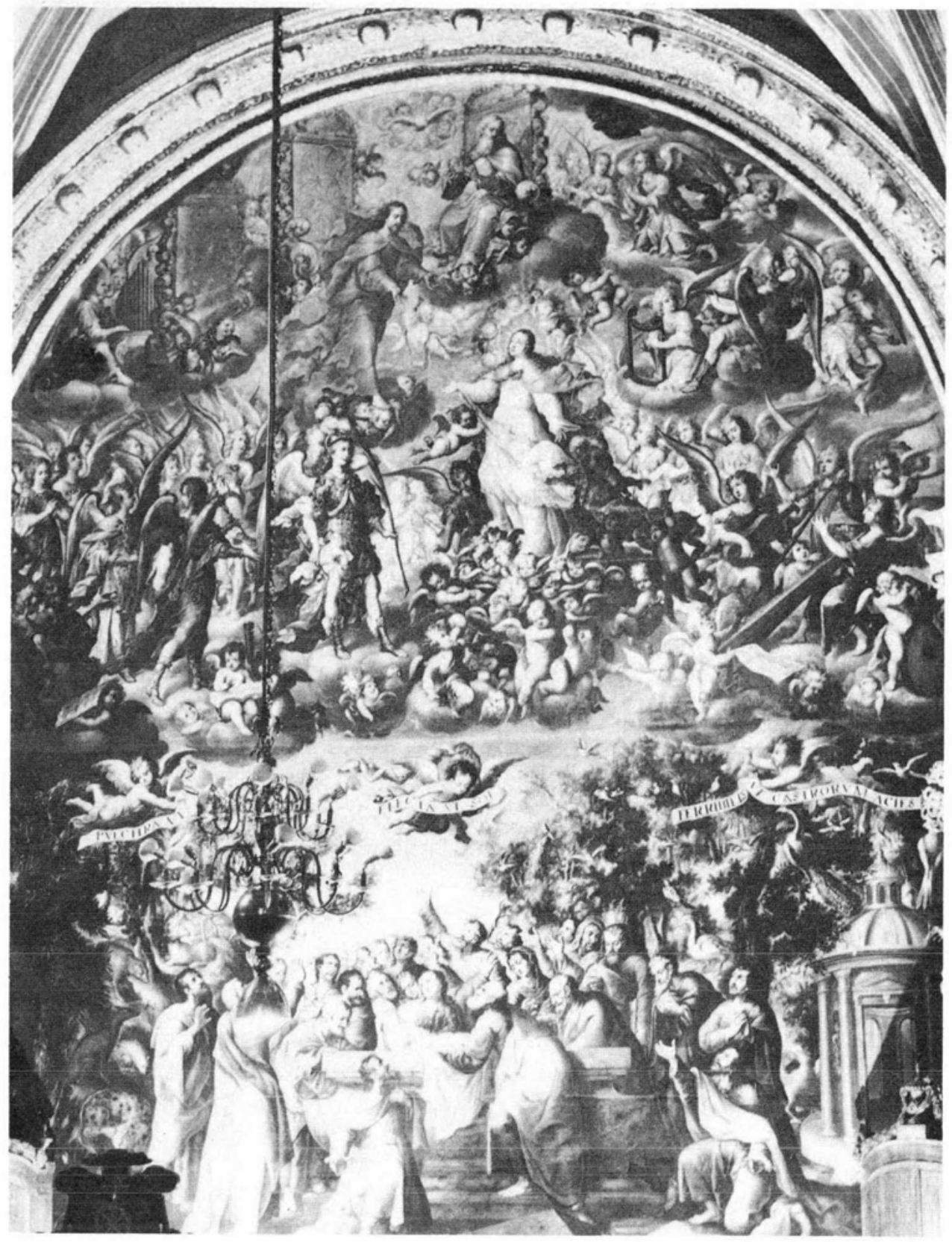

Figura 10. Juan Correa. Asunción-Coronación, 1689. Sacristía de la Catedral Metropolitana. 


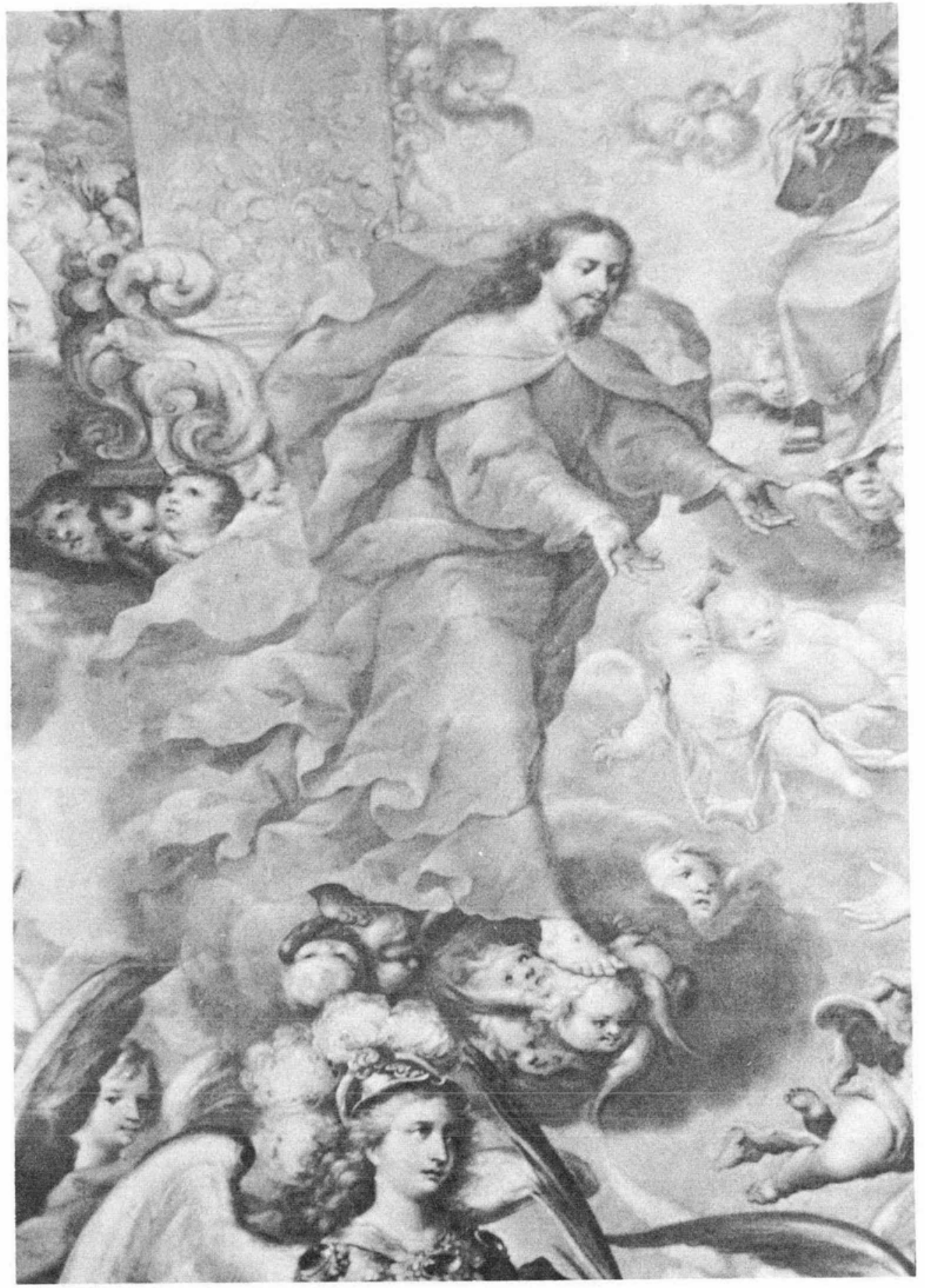

Figura 11. Juan Correa. Asunción-Coronación, 1689. Sacristía de la Catedral Metropolitana. Pormenor de la figura del Salvador. En la parte del fondo se ve uno de los tronos 
DOI: http://dx.doi.org/10.22201/iie.18703062e.1982.50\%20Tomo\%201.1141

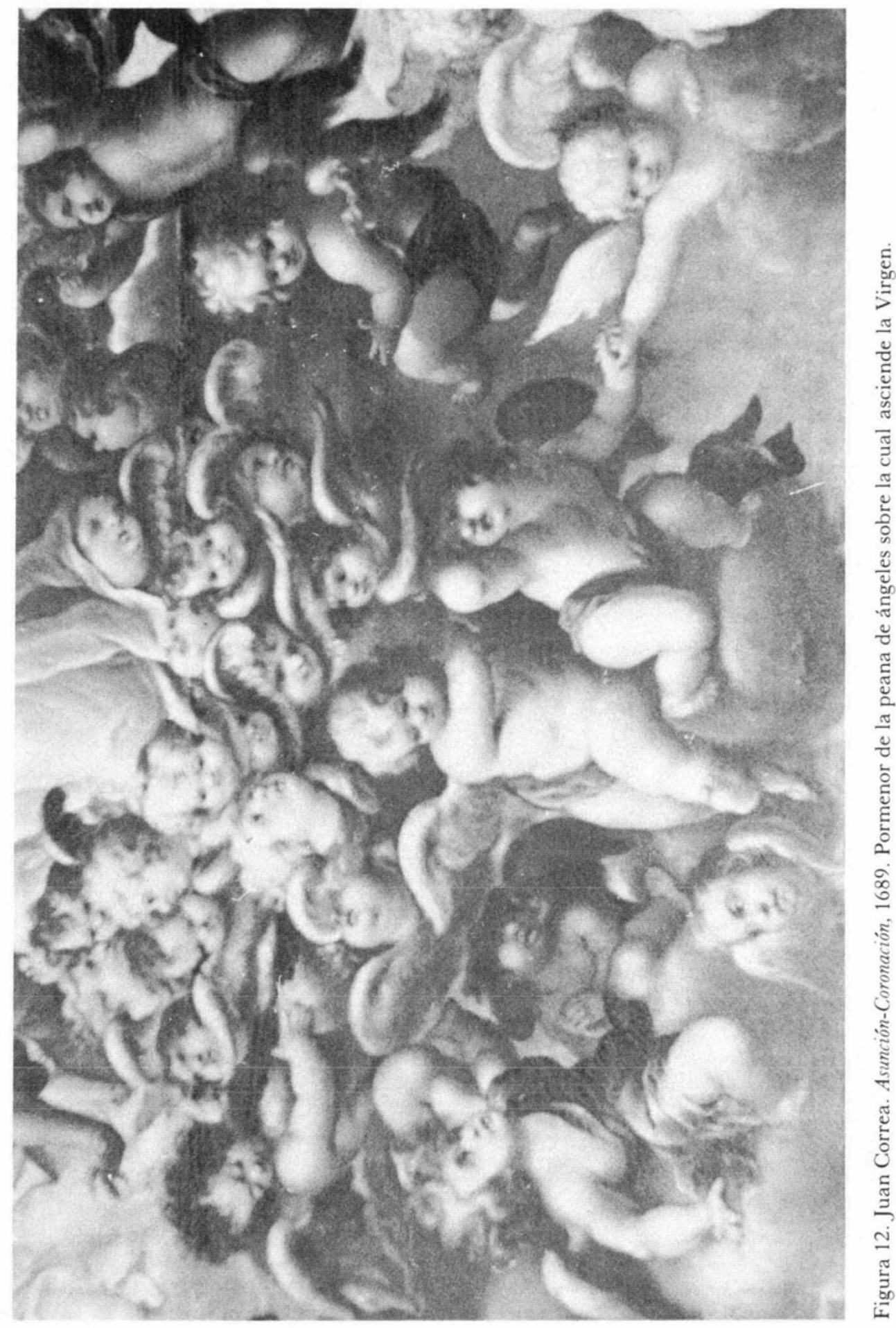


DOI: http://dx.doi.org/10.22201/iie.18703062e.1982.50\%20Tomo\%201.1141

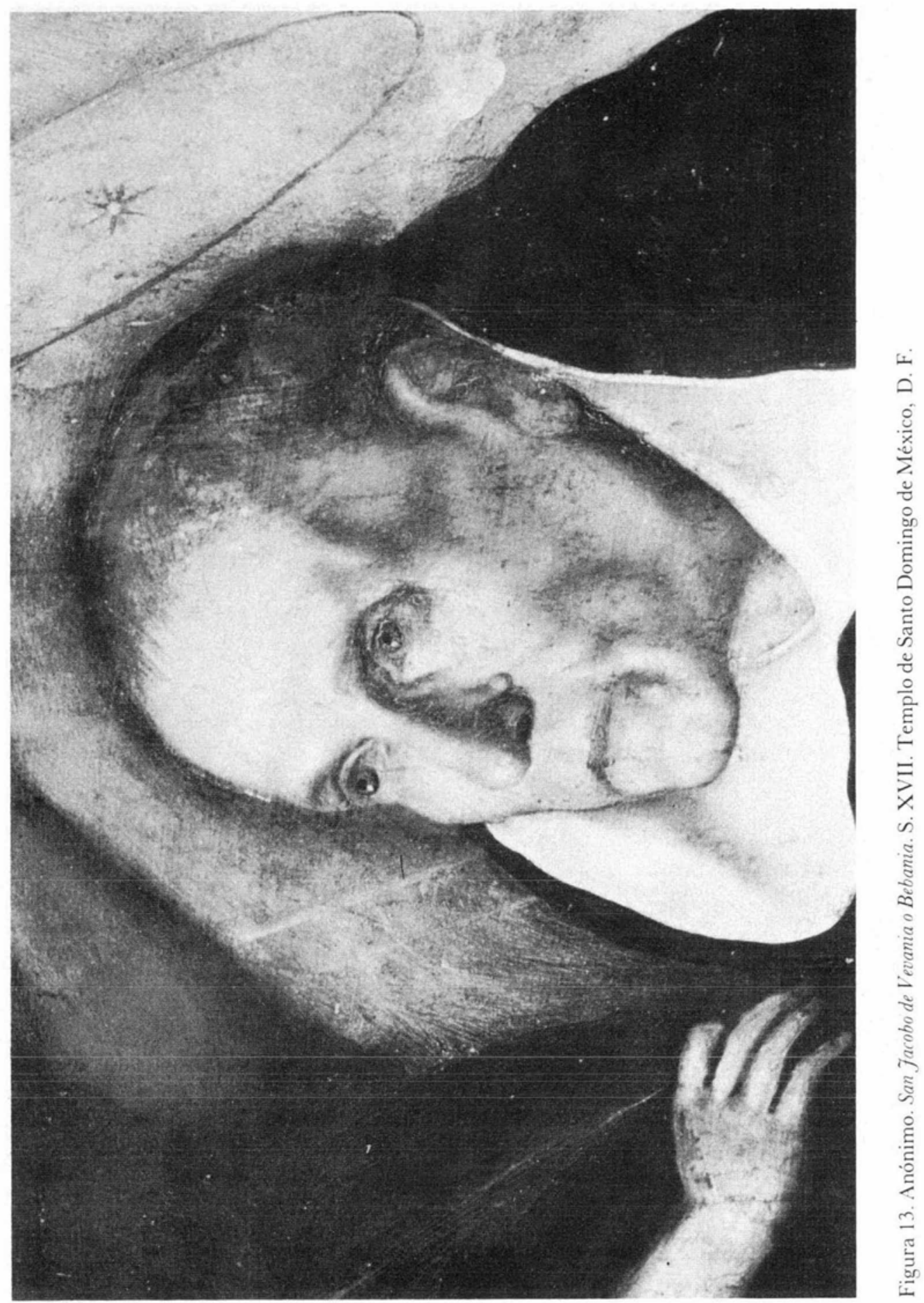


DOI: http://dx.doi.org/10.22201/iie.18703062e.1982.50\%20Tomo\%201.1141

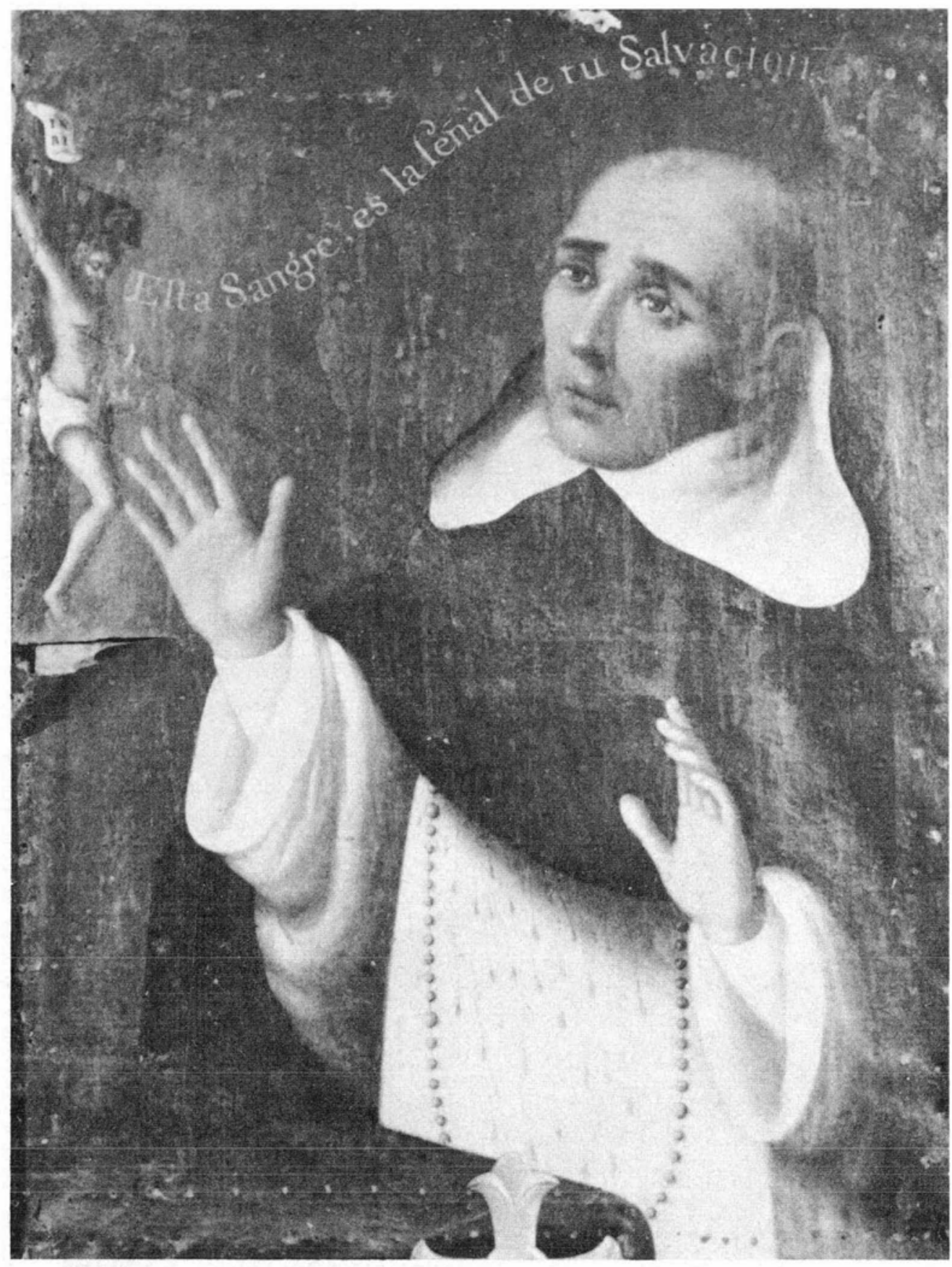

Figura 14. Anónimo. San Jacobo de Vevania o Bebania. S. XVII. Templo de Santo Domingo de México, D. F. 


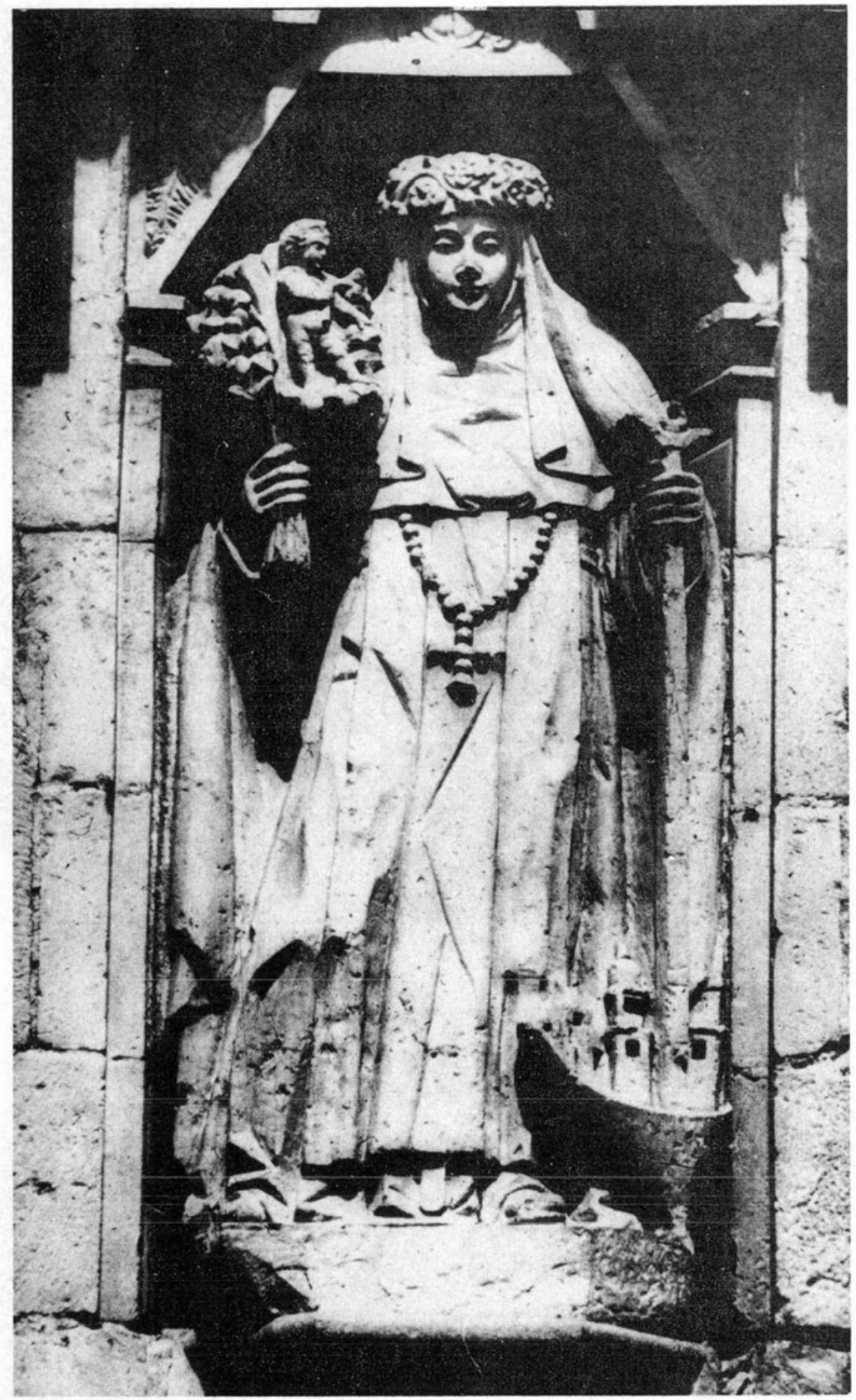

Figura 15. Santa Rosa de Lima. Fachada del Templo de la Soledad. Oaxaca, Oax. S. XVII. 


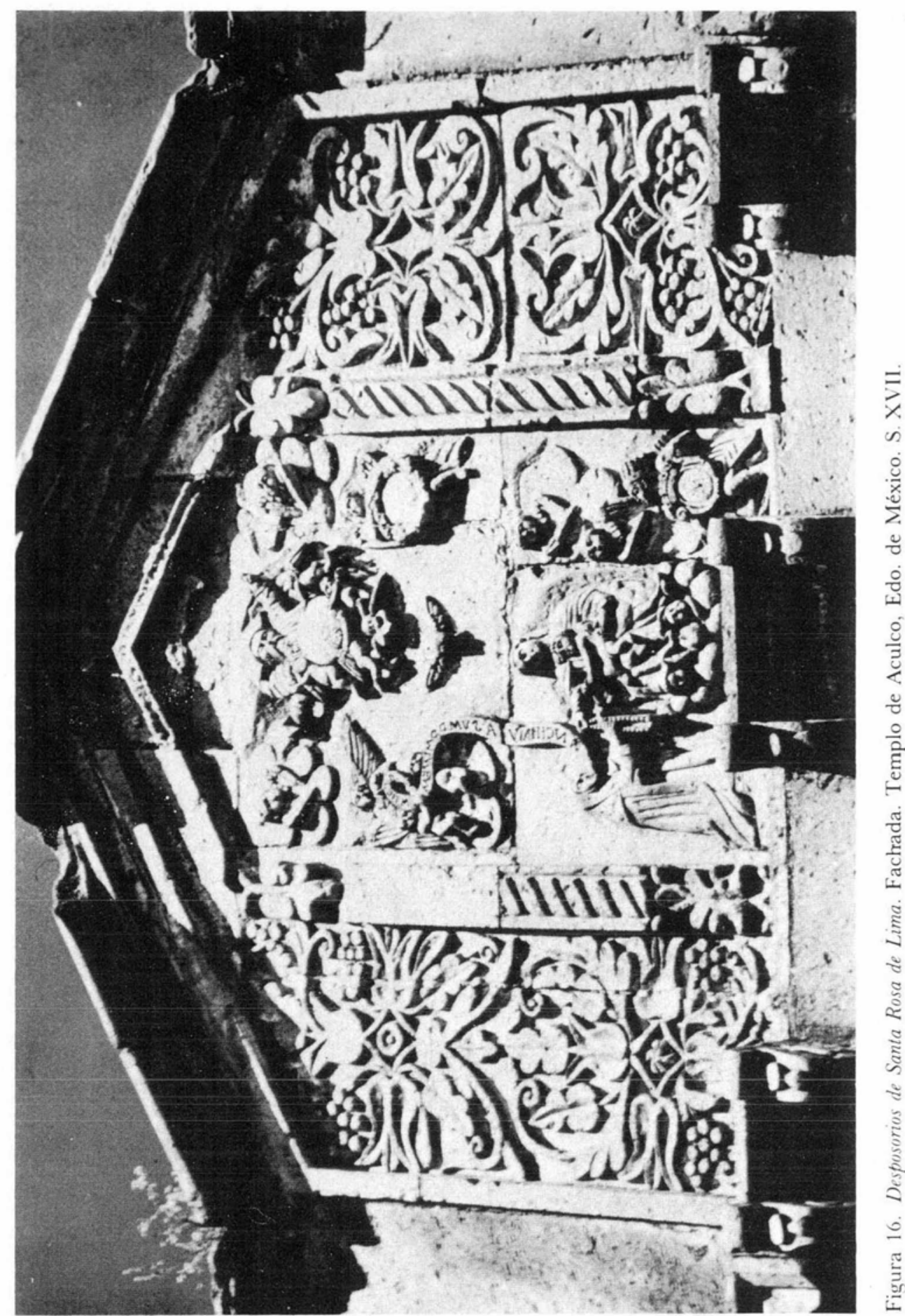


y convincente", ${ }^{16}$ congruente además con el pensamiento ortodoxo de la época, expresión, que - repito - tanta importancia tendría para definir años más tarde el paradigma de la pintura barroca.

"Pacificado" así el ambiente artístico, la expresión estaba perfectamente controlada cuando el arte barroco irrumpió en la Nueva España hacia mediados del XVII Señal de esta situación mantenida -además de la propia producción pictórica - parece ser el hecho de que durante más de siglo y medio no se volvió a convocar otro Concilio, ni se dictaron diferentes medidas para los artistas. Las Ordenanzas de 1686 - hechas con base a las aprobadas por Luis de Velasco en 1557 - contienen diez artículos administrativos, contra tres sobre técnica pictórica, ${ }^{17}$ a pesar de que el arte se había alejado de las formas renacentistas para introducirse en la corriente barroca Es decir que para la elaboración de las Ordenanzas las directrices artísticas no contaban para nada; lo importante era que se mantuviera la honesta expresión, independientemente del estilo. Con este motivo se insistió especialmente en que los Veedores se nombraran cada año y se vigilara que cumplieran su cometido. Es interesante recordar que se volvió a luchar por excluir a los indios del campo de la pintura, por considerar que sus obras eran irreverentes pero finalmente se decidió que pudieran entrar como aprendices y examinarse para pintar imágenes. ${ }^{18}$

\section{La pintura como objeto trasmisor}

Las sociedades americanas surgidas a raíz de la conquista, fueron desde el principio de la evangelización preparadas para recibir y comprender a través de la obra pictórica el mensaje moralizador que la Iglesia debía trasmitir. Dadas las peculiares circunstancias históricas de la conquista y colonización, la sociedad del tiempo barroco americano resultó ser sumamente compleja y contrastada, en todos los órdenes. La expresión pictórica habría de adecuarse a una realidad social verdaderamente intrincada, pues los destinatarios de la pintura barroca deberían ser - por igual- todos los hombres que la componían: peninsulares, criollos, autoridades civiles, clero, nobleza, letrados, ricos comerciantes y mineros, la plebe ignorante y pobre; los indios y las diversas castas que -especialmente en la Nueva España- matizaron prolijamente la sociedad. Empero, a pesar de tan hondas diferencias humanas la cohesión interna ejercida por la Iglesia logró unificar el lenguaje artístico para trasmitir su contenido didáctico y simbólico a todos los niveles. En la Nueva España, la numerosa población diversa y multicolor, de diferentes culturas, inteligencias, sensibilidades y riqueza, recibió el mensaje de la Iglesia a través del mismo objeto trasmisor: un

16 Francisco Stasny $O p$. ch

17 Manuel Toussaint. $O p$ all. p. 138

18 Ibulem Apéndice p. 223 a 226 Texto de las Ordenanzas de 1668 
determinado tipo de obra de arte. Por lo que toca a la pintura, se generó e impuso a la sociedad una misma manera de expresión, apoyada en formas de fácil comprensión, cuyo simbolismo religioso, cuando deseaba elevarse a mayor nivel intelectual recurría a sutiles elementos de erudición bíblica - que deben haber conmovido a los más conocedores - pero sin descuidar nunca el patrón formal, convencional que había de ser de claro lenguaje para ser captado por la mayoría de los entendimientos. Así, a través de los principios escolásticos rectores de la mente y del arte de la época, al servicio principalmente de la iglesia, la pintura barroca americana se vio ajustada a un tono medianero, artesanal y anónimo de preferencia, ecléctico y de fácil lectura, que fue el paradigma de su naturaleza y de su finalidad frente a la sociedad; y para poder ser obra útil dentro de ella.

Por otra parte, según consta en las instrucciones que los reyes daban a sus virreyes y las recomendaciones que éstos a su vez, daban a sus sucesores, a las autoridades civiles nunca les preocupó el fenómeno artístico . Definitivamente éste quedó en manos de la Santa Madre Iglesia. No existieron pintores independientes, apartados de los gremios, como en España, en donde la protección real produjo un mecenazgo semejante al de Italia que estimuló considerablemente la superación personal de los artistas. El pintor colonial trabajó siempre, obligadamente en un nivel artesanal y es posible que debido a ello, haya sido en América, mejor que en España, en donde se cumplió más apegadamente con la función utilitaria, didáctica y simbólica, que el Concilio de Trento preconizó para el arte. Testimonio de ello es la mayor parte de nuestra pintura colonial, de donde se procuró desterrar toda forma que pudiera verse profana, deshonesta, inovadora.

El modelo que se siguió - tal como puede juzgarse objetivamente en el acervo de pintura colonial que hemos heredado- para la representación de los temas religiosos, se recreó con base en un naturalismo relativo y cuidadoso, exento de detalles particularizantes, sin acercarse por lo tanto, a ningún grado de realismo que pudiera restar espiritualidad a las figuras sagradas, las cuales, por lo general ofrecen rostros inexpresivos, de facciones uniformes y actitudes reposadas como corresponde a su estado de gracia. Los fieles - hay que recordar - no deberían ver en ellas, a personas determinadas, de carne y hueso, sino sentir la presencia espiritual santificada, digna de veneración. Sólo en el caso de los personajes divinos se aplicaron mayores posibilidades de la dinámica formal barroca: grandes movimientos de paños y de alas; intenso claroscuro en los rompimientos de gloria; mayor policromía y lujo en los atavios etc.; empero los rostros conservaron siempre - válgase la frase- una dulce inexpresividad. Es el momento de recordar cuántas veces se ha señalado que en la pintura colonial los personajes sagrados ostentan rostros tan parecidos entre si que parecieran ser hermanos. Efectivamente, muchas veces, lo único que determina el sexo, es el largo de los cabellos, y la edad, su color. Esta expresión constreñida trascendió también a otros géneros de pintura colonial 
Como consecuencia directa de la aplicación sistemática de dicho paradigma pictórico, en América no se cultivó el realismo; de tan importante desarrollo y altura en la España barroca. Sin embargo, se conservan algunas estupendas creaciones de esta modalidad: el retrato de "Enrique Caldas Barbosa" (figura 6) obra del santafereño Gregorio Vázquez fechado en $1698^{19}$ que tal como acepta Diego Angulo Iñiguez ${ }^{20}$ es obra comparable a lo que entonces se hacía en la Península. En la capital de la Nueva España un pintor desconocido dejó el retrato de sor Ana de Neve (figura 7), uno de los mejores retratos de la pintura colonial de México; también equiparable a la pintura española de la época. La óptima calidad de oficio y expresión que presentan ambas obras, permite asegurar que en América sí hubo artistas con suficiente habilidad para haber podido cultivar con altura el realismo pictórico, pero que por ser éste, en buena parte contrario al ideal de belleza sagrada impuesto por la Iglesia, no progresó.

Prueba contundente de la aplicación de dicho paradigma formal que convertía a la obra pictórica en útil objeto trasmisor se observa claramente en el proceso iconológico que sufrió la representación de la imagen de santa Rosa de Lima. De esta santa peruana se conservan, una descripción de su rostro y un retrato hecho por Angelino Medoro (figura 8), inmediatamente después de que murió la joven; ${ }^{21}$ lo que acaeció en 1617. En las primeras representaciones de la santa, tanto peruanas como mexicanas, hubo el intento de darles el parecido real pero muy pronto se abandonó la idea y el rostro de Rosa de Lima se pintó de ahi en adelante con las mismas facciones convencionales utilizadas para los rostros femeninos del santoral: rostro ovalado y sonrosado, boca chica bien dibujada, nariz corta y recta, ojos oscuros, medianos, mirada arrobada y frente amplia. A tal grado su rostro real se desdibujó - gracias a la obligada receta para rostros de santaque de no ser por los atributos que generalmente la acompañan, prodría confundirse con otra de las santas dominicas, como de hecho ha sucedido (figura 9) De la misma manera, en general, para la identificación de santos y santas, es necesario desentrañar la iconografía que ofrecen los atributos que ostenten

Pocos casos hay como los de san Ignacio de Loyola, o san Felipe Neri, quienes sí se reconocen por ciertos razgos personales que, aunque no dejan de estar tratados convencionalmente, pueden considerarse como retratos en un sentido laxo.

\footnotetext{
19 El retratado era Rector del Colegio del Rosario de Santa Fe de Bogotá El pintor, Gregorio Vázquez, nació en Santa Fe de Bogotá en 1683 Cr. Diego Angulo Íñiguez Historia del Arte Hisfranomerciano Barcelona. Salvat 1950 T. II p 464

21) Ibudem.

21 Cfr Elisa Vargas Lugo "Proceso iconológico de santa Rosa de Lima". XLII Congreso Internacional de Americanistas. París. En Prensa
} 


\section{La indiscriminación de oficios}

En la Nueva España - tanto la pintura religiosa como en la de asuntos profanos- presenta una peculiaridad técnica muy importante: la indiscriminación de oficios . Es decir que en la mayoría de los casos - sin importar la categoría de la pintura - pueden distinguirse diferentes calidades de oficio en una misma obra o variar éste notablemente, de un cuadro a otro, en los conjuntos que constituyen series determinadas. En términos generales, el mejor oficio se ve en la representación de seres inanimados: joyas, muebles, telas, etc, y el de menor calidad en la representación de seres animados: plantas, animales y figuras humanas. Las razones para explicar este fenómeno son varias. Se viene desde luego, a la memoria, el hecho de que los pintores coloniales no observaron metódicamente la naturaleza. Por otra parte, seguramente que, no la copia fiel de los modelos grabados de que se servían nuestros pintores, sino la necesidad que tuvieron de invertir y modificar el or den de las composiciones de dichos modelos, para buscar soluciones novedosas, viciaron la calidad del dibujo. Lo mismo puede decirse que sucedió cuando los artistas se vieron en la necesidad de ampliar las composiciones basadas en pequeños modelos para crear obras de dimensiones muy grandes. Es un hecho que la pintura en lámina, en la Nueva España - casi siempre de pequeñas dimensiones - luce un oficio más cuidado y fino, de calidad más cercana a los modelos grabados, que los lienzos en donde hubo necesidad de agrandar mucho la composición. Otra causa determinante de este fenómeno fue el sistema gremial de trabajo que permitía que aprendices y oficiales intervinieran en obras aun de primera importancia. En muchas obras pueden detectarse con claridad varios oficios, bajo la firma de un maestro.

Pero lo importante de este hecho indiscriminatorio no es sólo explicar por qué tuvo lugar técnicamente hablando, sino las posibles razones sociales que no sólo lo permitieron, sino que hicieron que fuera conscientemente aceptado tanto por los artistas como por el público.

Salta a la vista que una de las razones debe haber sido el conformarse con la falta de mejores pinceles, pero creo también que el asunto contiene otras motivaciones más profundas. En el estudio de la estética barroca hecho a través del Retablo de los Reyes de la Catedral de México, por Justino Fernán$\mathrm{dez}^{22}$ se devela la existencia e importancia de un sentimiento de grandeza mexicana que animó en el espíritu criollo desde los albores de su existencia como clase social. Me parece que fue también debido a ese anhelo de grandeza que se aceptó a manera de voluntad artística, la mezcla de diferentes cailidades de oficio, aun en las grandes obras de la pintura colonial -y también de la escultura y arquitectura - puesto que lo importante era obtener el conjunto simbólico y grandioso; mostrar que en Nueva España se podían hacer tan buenas obras y tan importantes como en España Magnífico ejemplo de

${ }_{22}$ Clr Justino Fernández. El retablo de los Reyes México UNAM, 1959 
este peculiar fenómeno del barroco mexicano es la gran pintura de Juan Correa - que cubre uno de los muros de la sacristía de la catedral metropolitana - titulada Asunción-Coronación de la Virgen (figura 10), firmada en 1689. Este, uno de los más complicados y grandiosos logros del artista, muestra partes - como la figura radiante del Salvador - (figura 11), de gran elegancia y muy buen oficio, al lado de mediocres tratamientos como los desnudos de los amorcillos (figura 12), o las figuras de los animales que aparecen en la parte baja del cuadro que en algunos casos no ha sido posible identificar. En cambio eso sí, el conjunto es en verdad deslumbrante. De paso sea dicho, éste es uno de los casos en que el artista hizo gala de la más estricta y rebuscada erudición bíblica, para informar la composición. La mayoría del público podría reconocer en esta obra, el momento en que María fue elevada a los Cielos, pero sólo una minoría conocedora a fondo de las Sagradas Escrituras, podría gozar plenamente de la sugestiva idea de haber colocado cuatro tronos en la parte superior del lienzo, puesto que estos objetos aluden a ciertos pasajes de la vida del rey Salomón. ${ }^{23}$

Otro elocuente ejemplo de la incondicional aceptación de la diversidad de calidad en el oficio, son las dos representaciones del mencionado San Jacobo - San Diego de Bevania o Mevania que se conservan en el templo de Santo Domingo de la ciudad de México. Una de ellas es otra de las mejores creaciones de retrato (figura 13), que se produjeron en México; la otra en cambio, de pincel mediocre se atiene al modelo convencional (figura 14). No existe, por otra parte, ni el más remoto parecido entre las dos representaciones. Sin embargo ambas recibieron culto simultáneamente en el mismo templo Tan profunda diferencia de calidad entre estas pinturas y su total aceptación, como dignas representantes del mismo santo dominico, recuerdan el siguiente concepto tomista: "Lo importante no es que el artista opere bien, sino que cree una obra que opere bien. Lo que importa es la utilidad de la obra de arte y su participación en las necesidades del hombre". ${ }^{24}$ Es decir que tanto valía rezar frente a una obra de calidad, como frente a una representación mediocre. Ambas imágenes se suponian igualmente útiles para que los fieles les dirigieran sus plegarias. Resta añadir que este valor utilitario que se concedía a las obras de arte, las igualaba culturalmente y que esto, necesariamente, debió de haber sido también causa de la producción, muchas veces descuidada, que salía de los talleres; así como por otra parte, debió de haber puesto la pintura al alcance de casi todos los niveles sociales

\section{La proyección social a través del culto a las imágenes}

Aunque este aspecto de la pintura colonial está muy poco estudiado, las investigaciones de tipo iconológico han puesto al descubierto grandes y peque-

23 L.bro de los Reyes 11-19. Cfr. Elisa Vargas Lugo y Seminario de Arte Colonial Juan Correa, su rida y su rbra. En preparación. Temas Marianos Ficha 11.33.

24 Raymond Bayer. Historia de la Estética. México. Fondo de Cultura Económica 1965 p. 93 
ñas preocupaciones vitales de la sociedad criolla colonial, que se manifestaron a través del culto a las imágenes.

Dos cultos políticos se produjeron en América y cabe el honor de haberlos llevado a sus máximas posibilidades, a la sociedad novohispana: el culto guadalupano y el culto a santa Rosa de Lima (figura 15). Santa Rosa, la primera santa americana, fue canonizada en 1617 con todos los honores del caso. ${ }^{25}$ Aunque en Perú se desarrolló un encendido culto por ella -primero como don del cielo a la Orden dominicana y después como valor propio de los peruanos - fueron los criollos novohispanos - cuya naturaleza se encontraba en el conflicto ontológico de ser y no ser españoles,$-{ }^{26}$ quienes le dieron el valor propiamente americano, transfiriendo a él la anhelada bandera que, a socapa de la religión, pudiera representar sus más caros ideales - sociales y políti$\cos -$ y brillar con luz propia, con luz americana. Muchas pruebas documentales existen acerca de la rápida aceptación de este culto en la Nueva España y del carácter especulativo que se le dio. La razón por la cual los criollos mexicanos tomaron como bandera a santa Rosa en vez de abocarse al culto guadalupano se debe a que éste fue perseguido y discutido durante muchos años. Por esta razón a partir exactamente de 1668 en que la santa se beatificó, ${ }^{27}$ fue conveniente y menos peligroso exaltar el culto a santa Rosa ya que había sido autorizado por la Santa Sede. Su imagen representada en esculturas y pinturas pobló los altares y apareció, significativamente, en las fachadas de las más importantes catedrales y parroquias, como señal criolla, opuesta a lo peninsular. Por lo tanto el culto a santa Rosa debe considerarse como una etapa clave en el proceso de formación de los ideales nacionalistas de los criollos novohispanos. El criollismo, sin duda se afianzó con la oportuna aparición de la "estrella del Perú" y preparó la grandeza guadalupana.

Como es de figurarse, el suceso místico de los desposorios es -por su significación teológica - un tema central, no sólo en la iconología de santa Rosa sino en la de cualquier otra santa que haya gozado de tal distinción. Pues precisamente en la representación de los Desposorios de Rosa de Santa María con el Niño Jesús, es en donde los artistas modificaron sensiblemente la iconografía para introducir personajes que aludieran a la realidad americana. Basten dos ejemplos para ilustrar estas afirmaciones. Uno de ellos es una lámina de autor limeño, anónimo, al parecer del siglo XVIII, en donde aparecen, a los pies de la escena milagrosa - arrodillados y asombrados - algunos indios peruanos y dos o tres negros. El otro ejemplo es obra mexicana del siglo XVII - también anónima - que se conserva en el templo dominico de la ciudad de Puebla. A los pies de la escena aparece una figura de indio con un escudo en el que aparecen tres coronas, insignia de la ciudad de los Reyes de

\footnotetext{
${ }^{25}$ Cfr. Elisa Vargas Lugo "Una bandera del criollismo". Del Arte. Homenaje a Justino Fernández, UNAM $1977 \mathrm{p} 191$

${ }^{26}$ Cfr. Edmundo O'Gorman, "Meditaciones sobre el criollismo". México Condumex 1970.

${ }^{27}$ Elisa Vargas Lugo Op cit.
} 
Lima. En ambos casos se introduce así, en la composición -en un primer término- el elemento americano determinante en el origen del culto y de paso se ha dicho, en México los criollos no se conformaron con señalar lo americano a través de un símbolo peruano, sino que se apropiaron de dicho símbolo; prueba de ello es el bajo relieve que remata el templo de Aculco en el estado de México (figura 16), en donde la figura del indígena, lleva en su escudo, en vez de la heráldica limeña, la $M$, de México.

En el caso de la iconografía guadalupana el interés nacionalista se mezcló con la más alta ambición teológica y se produjeron muy interesantes composiciones en torno a la imagen de la Virgen del Tepeyac (figura 17). En una de ellas se colocó a San Lucas retratando a la Guadalupana; otra pintura muestra al Padre Eterno coronando a la Virgen y otra -casi increíble- presenta al Espíritu Santo (figura 18), pintando personalmente a la Virgen de Guadalupe. Todos estos esfuerzos y osadías teológicas tuvieron lugar obviamente por el afán de dar apoyo escritural a la aparición.

En otros casos se quiso poner de relieve la importancia propiamente social de la aparición, hecho que -lógicamente, dentro del sentido providencial de la existencia - vino a igualar, a dar fe y reconocimiento de la categoría espiritual e individual, de la Nueva España, como "nación", frente a la Madre Patria y de América, el nuevo mundo, frente a Europa, el viejo mundo. Estas pinturas son obras del siglo XVIII, hechas en el apogeo del culto guadalupano, lo cual explica en buena parte su tono triunfalista.

Otra interesantísima composición guadalupana, que Francisco de la Maza dejỏ registrada en su citada obra es la iconología Guadalupe-Asunción ${ }^{28}$ (figura 19). Es decir que se buscó representar la nueva advocación integrada hasta donde fue posible a los más significativos momentos de la historia mariana. Lo más interesante para la finalidad de este trabajo es señalar el esfuerzo que hicieron constantemente los teólogos mexicanos -ya por medio de la literatura, ya por medio de la pintura - por dotar a la Virgen aparecida en México - pero no reconocida por Roma- de toda clase de significados escriturales y marianos, con el fin de demostrar y propalar su autenticidad divina

Corresponde mencionar aquí las estupendas y exclusivas creaciones de ángeles, que se originaron en el virreinato peruano, como uno de los más valiosos y singulares frutos del barroco americano; en especial los lilamados arcabuceros (figura 20), con trajes de la milicia del siglo XVII - tal como informan Mesa y Gisbert $-{ }^{29}$ rico atuendo que los ha hecho famosos. A pesar de que sus ropajes derivan de modelos principalmente flamencos, el empleo de oro y de un brillante colorido de raigambre local, los convierte definitivamente, en obras no sólo distintas, sino opuestas al concepto ortodoxo de lo angelical. La interrogante que existía acerca del significado de los arcabuces en manos de

\footnotetext{
${ }_{28}$ Francisco de la Maza El guadalupanımo mexicano México Porrúa 1953.

29 Teresa Gisbert y José de Mesa Holguin y la pinutu virreinal en Bolwia. La paz 1977. p 99 y 
los ángeles, ha sido esclarecida por Francisco Stasny quién develó el sincretismo cultural que transfirió el concepto prehispánico del poder sobrenatural del trueno al ruido que emite el arcabús en relación con la función vigilante de los ángeles, creándose así esta novedosa y americana iconografía. Además - según ha observado acertadamente Manuel González Galván- estas pinturas ejemplifican estupendamente ese otro mecanismo pictórico tan propio de América -ya mencionado- que fue la monumentalizacion de los modelos grabados.

Un aspecto casi desconocido de la pintura barroca americana es la participación activa de las castas en este oficio. A pesar de que, según las Ordenanzas, en la Nueva España estaba prohibido que los mulatos -y se sobre entiende que menos aún los negros- pudieran ser aprendices de pintor, es un hecho comprobado - por las informaciones que proporcionan desde el siglo XVII los mismos virreyes ${ }^{-30}$ que en las manos de las castas recayó el desempeño de casi todas las labores artesanales, incluyendo la pintura. Ha sido una verdadera sorpresa descubrir que Juan Correa, importante pintor barroco del siglo XVII, mexicano y artista predilecto de la catedral Metropolitana, fue mulato y aunque su pintura no se señala de manera particular por este hecho racial, no es casual que en su pequeño lienzo "Niño Jesús con ángeles músicos" (figura 21), haya representado a uno de ellos con tipo mulato, seguramente por anhelos subconscientes de igualdad social. Tal vez por razones similares, a mediados del siglo XVIII, el pintor poblano Luis Berrueco, en dos series que pintó c. $1745^{31}$ - una sobre la vida de san Francisco de Asís (figura 22), y otra sobre la vida de San Juan de Dios - incluyó en las composiciones extraordinarias figuras de criadas negras, al lado de sus señoras, pero de ninguna manera en un plano de inferioridad, sino estupendamente vestidas y alhajadas, integradas dentro de un alto nivel social. Por otra parte estas obras religiosas, en las que aparecen mujeres comunes tienen el mérito de dar - junto con otra del pintor, también poblano, Joaquín Magón - un tratamiento especialmente lucido y muy barroco a las figuras, con lo cual se produce en las pinturas un tono mundano que las hace excepcionales. Son evidentemente obras de tono más decorativo que piadoso y que se salían de los cánones establecidos. En suma son obras de gusto más personal, aunque no lleguen a ser totalmente originales.

En la capital del virreinato no se presentó este fenómeno de gusto decorativo y feminista en la pintura religiosa. Mientras Pablo de Talavera, Luis Berrueco y Joaquín Magón la hacían en Puebla, en México, Francisco Vallejo y Miguel Cabrera llenaban los templos de pinturas estrictamente piadosas, muy dulzonas y suaves, que cuidaban meticulosamente de cumplir con las re-

\footnotetext{
${ }^{30}$ Las virreyes españoles en América, durante el gobierno de la Casa de Austrna Edición de Lewis Hauke, Madrid. Biblioteca de Autores Españoles. 1977. T. V. p. 12

${ }^{31}$ Cfr. Elisa Vargas Lugo y Marco Díaz, "Historia, leyenda y tradición en una serie francisca. na". Anales del Instituto Investigationes Estéticas México. UNAM 1976. Vol. XII . No. 44 p 59.
} 
DOI: http://dx.doi.org/10.22201/iie.18703062e.1982.50\%20Tomo\%201.1141

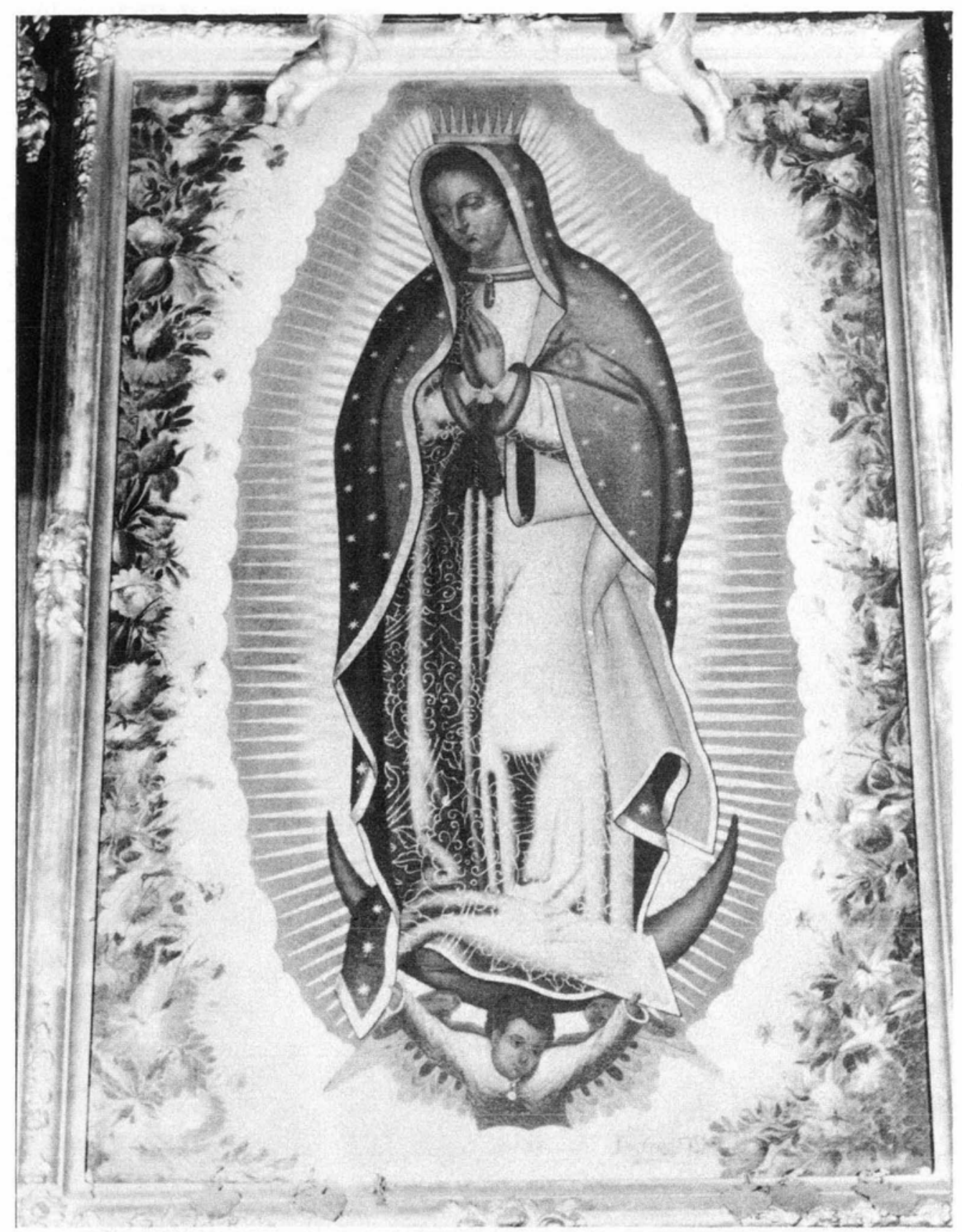

Figura 17. Juan Correa. I'irgen de Cimadalupe. S. XVII. Templo de Santo Domingo, Puebla, Pue. 
DOI: http://dx.doi.org/10.22201/iie.18703062e.1982.50\%20Tomo\%201.1141

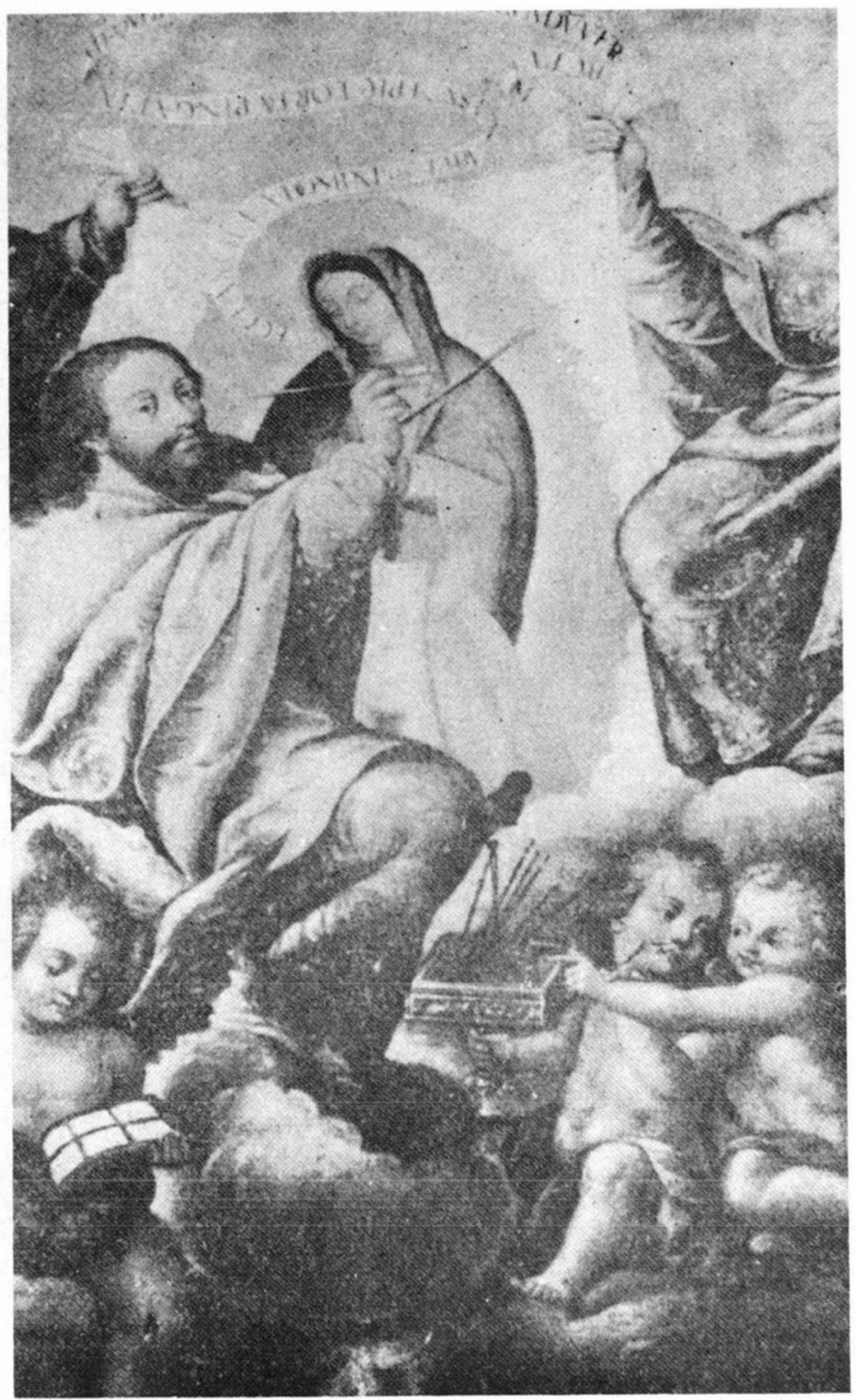

Figura 18. Anónimo. El Espíritu Santo pintando a la Guadalupana. Se desconoce su paradero. 


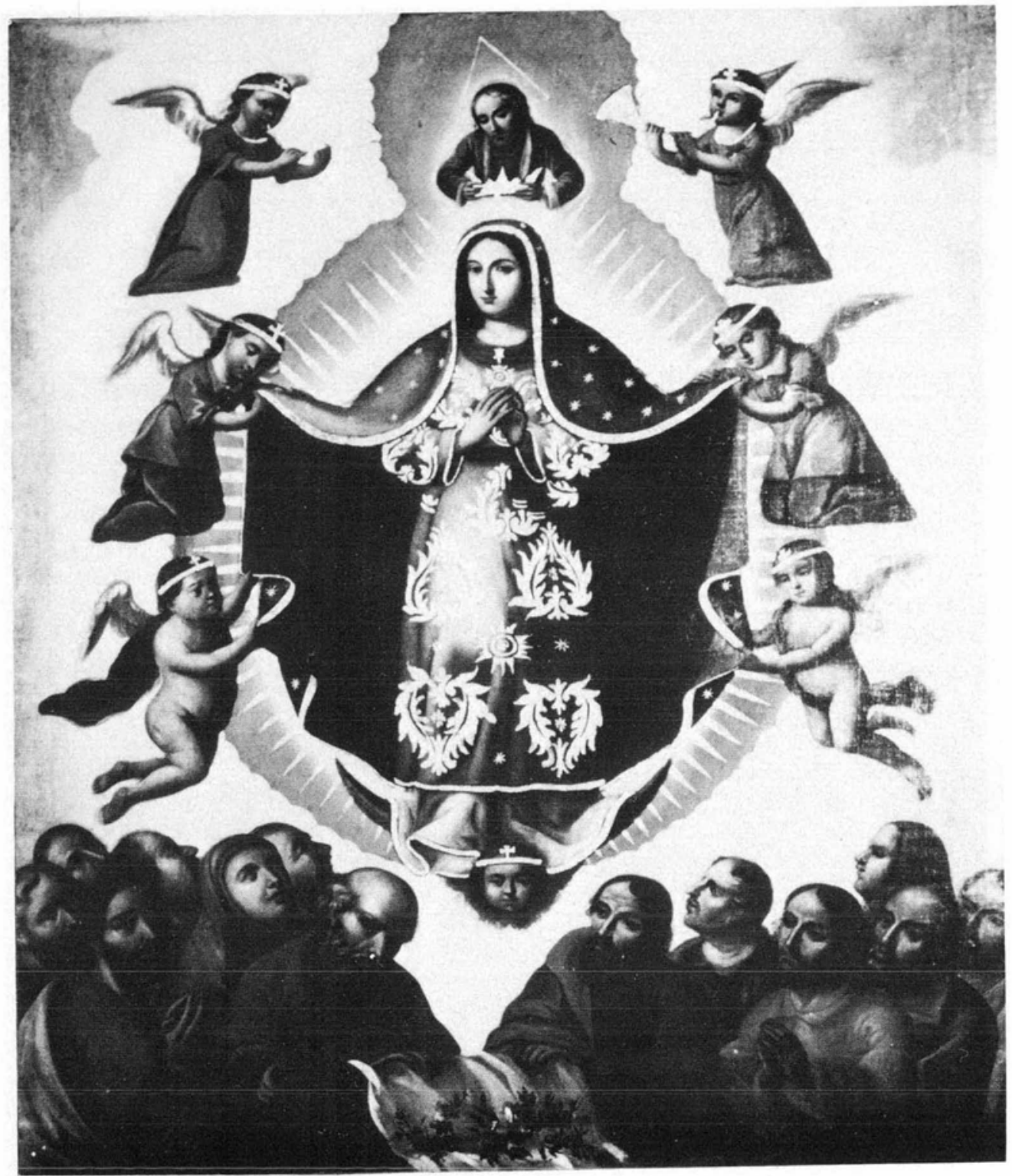

Figura 19. Anónimo. Guadalupe-Asunción. Paradero desconocido. 
DOI: http://dx.doi.org/10.22201/iie.18703062e.1982.50\%20Tomo\%201.1141

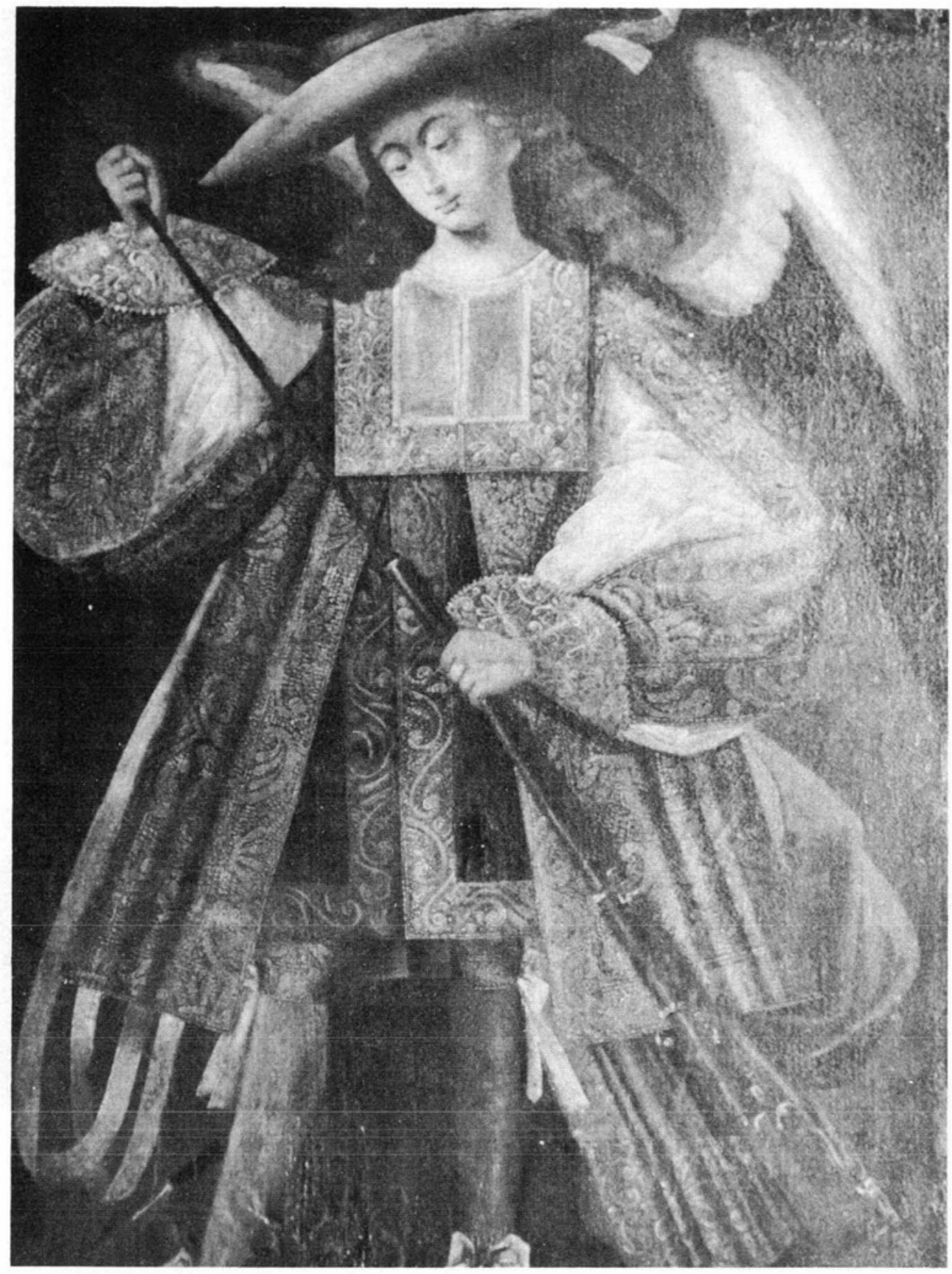

Figura 20. Anónimo. Arcángel Arcalencero. Pintura Peruana. 
DOI: http://dx.doi.org/10.22201/iie.18703062e.1982.50\%20Tomo\%201.1141

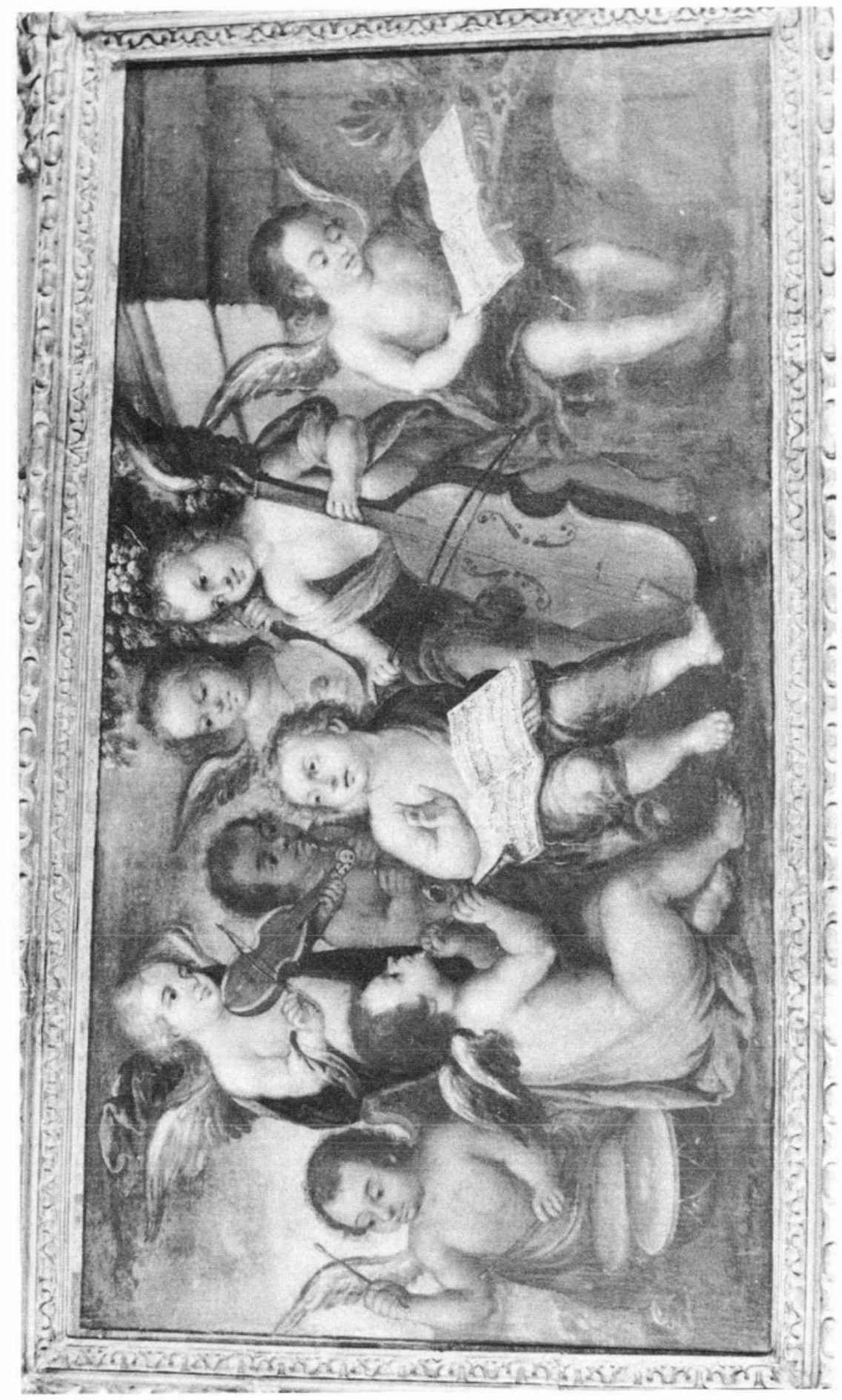

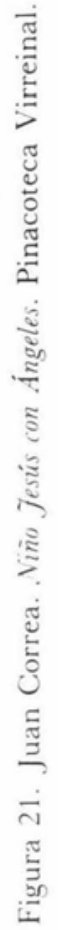




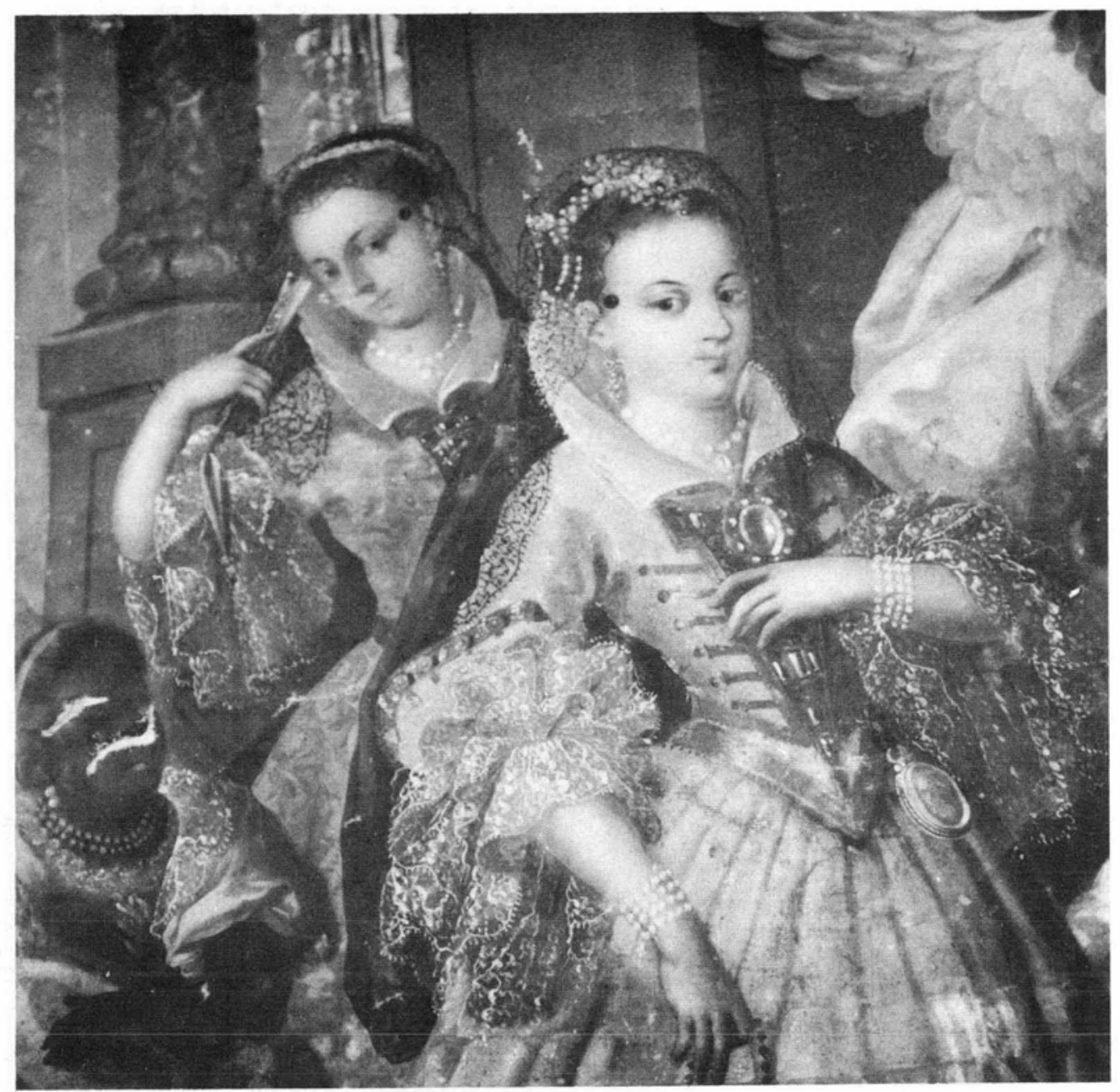

Figura 22. Luis Berrueco. Fragmento del Bautizo de San Francisco de Asis. C. 1745. Templo del convento franciscano de Huaquechula, Pue. 
DOI: http://dx.doi.org/10.22201/iie.18703062e.1982.50\%20Tomo\%201.1141

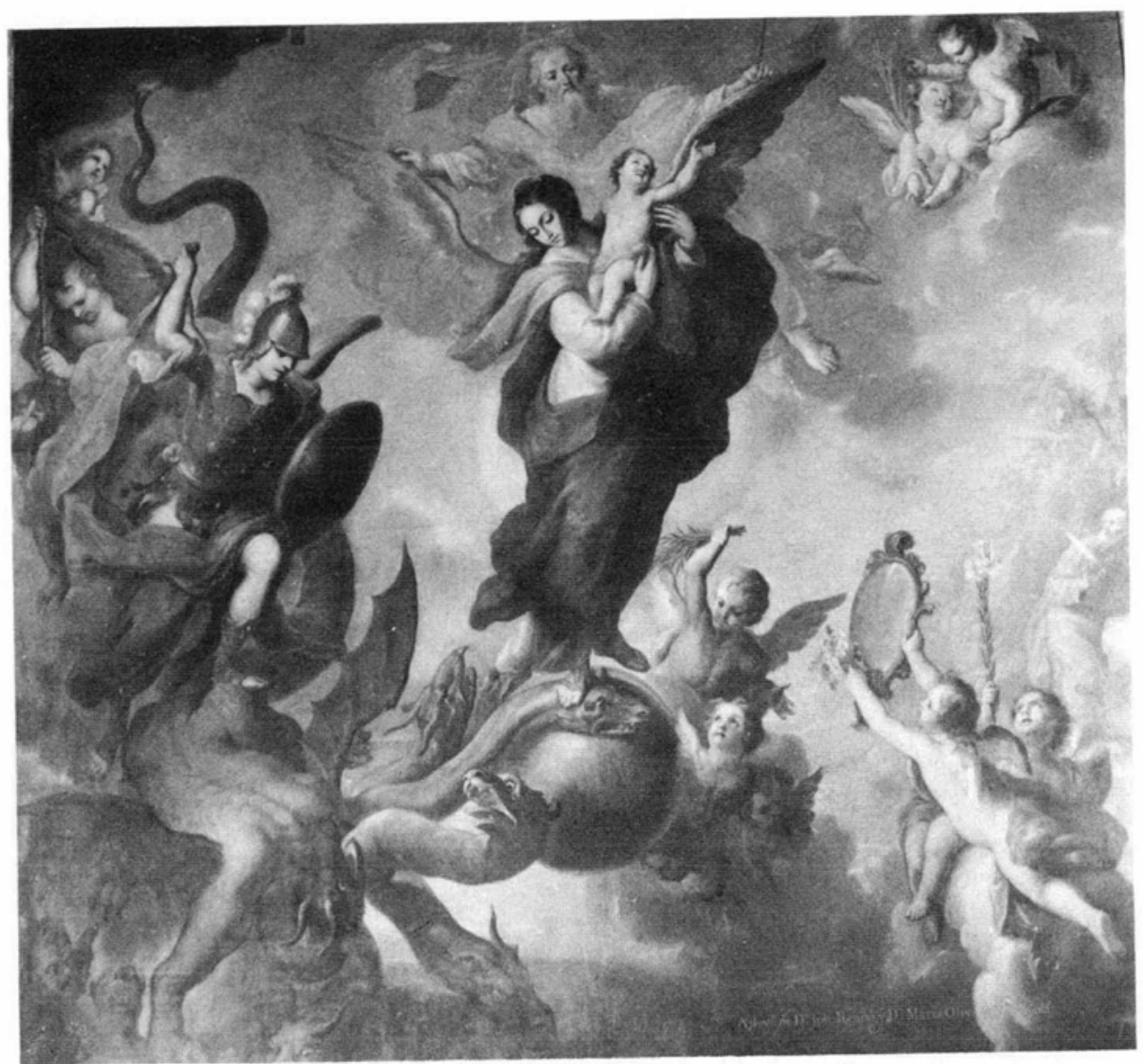

Figura 23. Miguel Cabrera. Virgen del Apocalipsis. S. XVIII. Pinacoteca Virreinal. México, D. F. 
DOI: http://dx.doi.org/10.22201/iie.18703062e.1982.50\%20Tomo\%201.1141

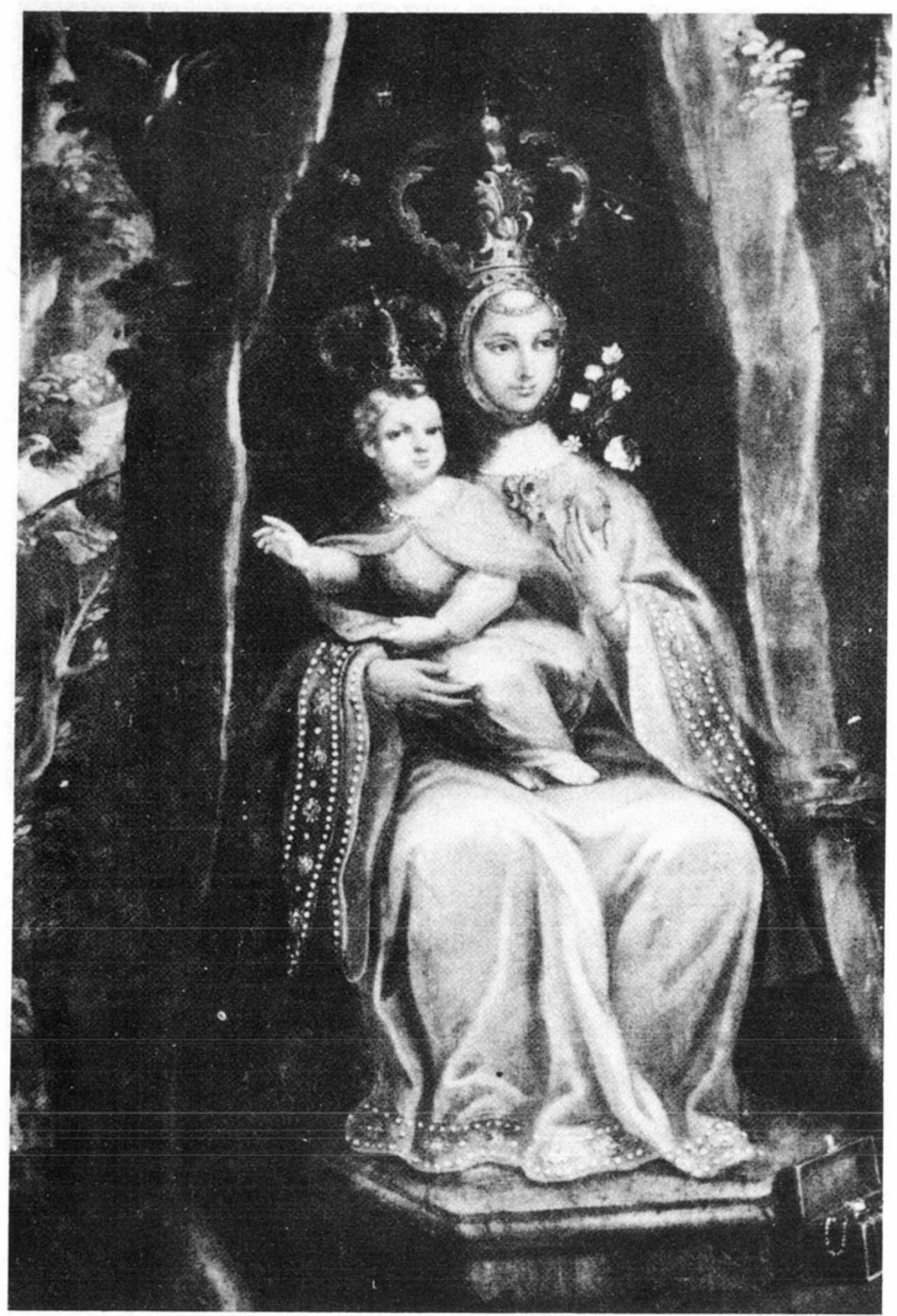

Figura 24. Miguel Cabrera. Virgen de Balvanera. S. XVIII. Museo de Denver, Colorado, U.S.A 
comendaciones tridentinas Posiblemente pinturas como las de Berrueco y Magón y otras, más atrevidas quizá - que tal vez hayan sido modificadas o destruidas - pudieron haber provocado la última y muy importante reacción de la Iglesia colonial, por conservar la pureza de la expresión pictórica en el último tercio del siglo XVIII.

\section{La pintura angélica}

1) acuerdo con el acervo de pintura colonial que se conserva en México, se diría que el control del fenómeno estético fue un hecho consumado desde que, a principios del siglo XVII se impidió el desarrollo del manierismo que profesaba Echave Orio Sin embargo existen importantes sintomas indicadores -a partir de 1750- de una ola de inquietud que se despertó entre los pintores más reconocidos del momento, en relación con la expresión pictórica; alarma que se vio apoyada en 1771 cuando se celebró el Cuarto Concilio Eclesiástico Mexicano.

Un grupo de pintores, entre los que hacía cabeza Miguel Cabrera, creyeron necesaria la fundación de una Academia en el seno de la cual unos a otros se ayudaran para mejorar dicho arte, pues: "Causan horror ... tantos abusos como produce la ignorancia en Efigies, Retablos, y Públicos Oratorios. No vemos más que nuestra propia deshonra en manos de los Indios, Españoles y Negros, que aspiran, sin reglas ni fundamentos a la imitación de los objetos santos". 32 Para esta Academia - que aparentemente nunca llegó a funcionar - se hizo un Reglamento que en su Capítulo IX prohibía que los pintores aceptaran aprendices que no fueran descendientes de españoles: "Ninguno puede recibir aprendices de color quebrado ...", ${ }^{33}$ dice el texto.

El aumento de los pintores de "color quebrado" debe haber sido importante y creciente, pues más tarde el virrey Bucareli -que gobernó entre 1771 y 1779- dejó escrito, al referirse a las castas: "De esta clase de gente se componen todos los gremios: Pintores, plateros, sastres... que con habilidad para todo, y ganando crecidos jornales los pocos días que se sujetan al trabajo, lo demás del tiempo lo emplean en la embriaguez y los vicios... "'34

Seguramente el acceso de personas no agremiadas ni preparadas en el campo de la pintura, produjo libertades que, aunque resulten dificiles de probar, debieron haberse dado en número y grado importante puesto que la Iglesia, en el Concilio de 1771 dictó las siguientes enérgicas medidas sobre el asunto:

"En la pintura de imagenes - dice el texto- se han introducido no menos corruptelas por los pintores, contra todo el espíritu de la Iglesia, y en deshonor

32. Ibelardo Carrillo y Gariel El pntor Miguel Cabrera México INAH 1966 p 19

33 Ihuthm $\mathrm{p} 18$

34 Rómulo Velasco Cevallos La Admmistractón de Fray Antomo Ma de Bucareli y Ursia. México 1936 T. 11 p 58 
de los Santos, ya pintando a Ntra. Sra y a las santas con escote, y vestiduras profanas de que nunca usaron; ya descubiertos los pecho; y en ademanes provocativos; ya con adornos de las mujeres del siglo; y casi el mismo abuso se nota en los escultores, por lo que manda este Conculio, se borre, y quiten semejantes imagenes; y se ordenó que ni por los Pintores, Escultores ni otra persona, se pinten o esculpan Historias fabulosas de santos, sino que en el modo y compostura se arreglen a las Sagradas Escrituras y Tradición; pués puede entrar en lo sagrado conscupiscencia por los ojos viendo mujeres deshonestas o niños desnudos, y lo que creen es ternura o devoción, es pura sensualidad ... y los pintores se abstengan de pintar cosas provocativas aún en las imagenes que no sean de santos, pués de lo contrario echan sobre sus almas los pecados y ruinas espirituales de todos los que caen al ver aquellas imagenes inmodestas" 35

El Concilio publicó además unas Reglas para que fueran observadas por los pintores. En ellas se recuerda que el artista:

"No puede ni tiene arbitrio ... para figurar según su capricho[es decir para crear] nuevos modos, nuevas revelaciones, nuevos pasajes ... por que las pinturas son unos instrumentos... son unas lecciones, que entran por la vista, aún de los ignorantes. son unos aparatos de fantasía arreglada a los principios sólidos del arte ... para poner como vivo lo cierto .... el pintor bueno en lo sagrado es un predicador mudo ... el pintor no puede acomodarse al gusto desarreglado del que le encarga una nueva pintura y debe desecharle con fortaleza, aunque le ofrezca muchos caudales, diciendole: primero es mi Dios, primero es mi arte, primero es mi alma y mi crédito .." ",

Como seve, a dos siglos de distancia y justamente cuando en Europa imperaba ya la filosofía racionalista - que de alguna manera se habia infiltrado en la Nueva España - lá Iglesia continuaba áfer rada a la filosofía escolástica y a las directrices artísticas emanadas del Concilio de Trento y exigía, igual que en el siglo XVI, con renovado empeño, la incondicional sumisión por parte de los pintores. Aparentemente las nuevas medidas dictadas por el Concilio de 1771, produjeron sus efectos pues las pinturas del último tercio del XVIII - especialmente las de Miguel Cabrera y de Vallejo- parecen aún más cercanas al concepto tridentino del arte, que las de la segunda mitad del siglo anterion

José González del Pinal, canónigo de la Colegiata de Nuestra Señora de Guadalupe de México, en su aprobación a la obra de Miguel Cabrera, Maraiilla Amencana y conjunto de raras maravillas de 1756 dice que Miguel Cabrera era digno de los elogios

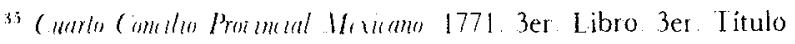

st Juan Iejeda Ramiro off al Vol. VI p 303-304 
".. que a otros peritos del arte.da don Antonio Palomino ... [cuando dice que] no solo es la pintura universal idioma, sino lenguaje Angelico, pués si los ángeles con una vista manifiestan los conceptos unos a otros, la Pintura manifiesta luego al punto lo que gastara muchas hojas un libro para explicarlo: y por eso sin duda (con sus palabras), han sido tan eminentes Pintores los Rafaeles y los Micheles para calificar ser arte de ángeles... ya debe entrar entre estos Miguel Cabrera, pués no menos en lo que pinta que en lo que discurre parece hacerlo como un Angel...",3?

Aunque estas hiperbólicas frases parezcan ahora cursis y exageradas, es evidente que Miguel Cabrera en ese momento merecía tales elogios por ser -para el gusto de entonces - el mejor tepresentante de "la pintura angélica" que Antonio Palomino - a quien tanto admiró y siguió nuestro pintor - preconizó e intentó fundamentar filosóficamente en su obra El Museo Pictórico ${ }^{38} \mathrm{La}$ información e inspiración que Miguel Cabrera obtuvo tanto de Palomino como de Francisco Pacheco, ha sido demostrada en la monografía escrita por Abelardo Carrillo y Gariel ${ }^{39}$ Sin duda que los textos de estos dos tratadistas españoles influyeron definitivamente en su manera de pintar, pero por otra parte su profunda fe, ciega - como demostró tenerla al hacer su estudio sobre la pintura de la Virgen de Guadalupe- su ansia de ser un verdadero "predicador mudo" y de que la pintura conservara su pureza expresiva, de acuerdo con la Iglesia, determinaron su voluntad artística Cabrera logró consagrarse como el más gustado de los pintores de su tiempo y por eso, no en balde, la tradición escrita trajo hasta nuestros dias la fama de este pintor, como el supremo pincel del siglo XVIII. Algunos estudios modernos han intentado disminuir su figura y otros, como el de Carrillo y Gariel, lo han juzgado objetivamente. Sin embargo si su obra se considera bajo la luz de las últimas disposiciones ordenadas por el Concilio Eclesiástico, se comprenderá el por qué de la mesura, dulzura, suavidad y recato de sus personajes sagrados, entre los que destaca la delicadeza de las etéreas representaciones del Padre Eterno, a quien vistió casi siempre de color de rosa. De la misma manera se explica la cuidadosa repetición de un ideal de belleza sagrada que hermana a sus personajes. Miguel Cabrera buscó y logró sin duda expresar la "pintura angélica" y con ella conquistó a la sociedad novohispana. Su obra se convirtió, ni más ni menos, en el justo paradigma de la belleza sagrada tridentina, simbólica, trasmisora de ejemplaridad, que "luego al punto" era comprendida por todos y los conmovía a piedad (Figuras 23 y 24 )

Sin dejar de reconocer el triunfo de la imposición dogmática, limitativa del impulso creador de los artistas que tuvo lugar en América, espero que a través de estos comentarios se haya hecho alguna luz sobre la proyección vital de

${ }^{37}$ Miguel Cabrera Harailla americana y conjunto de raras maravillas México 1756 p. s/n

${ }^{38}$ Cfr. Antonio Palomino de Castro y Velasco. El Museo Pictórico y escala ópllica Madrid 1715.

1 I Theorica de la Pintura

${ }^{9 y}$ Carrillo y Gariel Abelardo, Op cit 
DOI: http://dx.doi.org/10.22201/iie.18703062e.1982.50\%20Tomo\%201.1141

la sociedad novohispana cuyas urgencias ontológicas indudablemente informaron y diferenciaron, en lo posible, la obra pictórica novohispana, aunque esta proyección haya de encontrarse a socapa de los temas religiosos. 